\title{
Yiyecek İçecek İşletmelerinde Hizmet Kalitesinin Müşteri Vatandaşlık Davranışına Etkisi: İstanbul Örneği (The Effect of Service Quality on Customer Citizenship Behavior in Food and Beverage Enterprises: The Case of İstanbul)
}

\author{
Nihan YARMACI ${ }^{\text {D }}$ a Edanur KEFELI iD $_{b}$ \\ a İstanbul Gedik Üniversitesi, Güzel Sanatlar ve Mimarlık Fakültesi, İstanbul, Türkiye. nihan.yarmaci@gedik.edu.tr \\ b İstanbul Gedik Üniversitesi, Sosyal Bilimler Enstitüsü, İstanbul, Türkiye. edanurkfl@gmail.com
}

\begin{tabular}{|c|c|}
\hline MAKALE BİLGİSİ & ÖZET \\
\hline $\begin{array}{l}\text { Anahtar Kelimeler: } \\
\text { Müşteri Vatandaşlık } \\
\text { Davranışı }\end{array}$ & $\begin{array}{l}\text { Amaç - Bu araştırmada, İstanbul'daki Turizm İşletme Belgeli } 1 . \text { Sınıf Restoranlardan hizmet alan } \\
\text { bireylerin hizmet kalitesi algılarının müşteri vatandaşlık davranışı üzerindeki etkisini belirlemek } \\
\text { amaçlanmaktadır. }\end{array}$ \\
\hline Hizmet Kalitesi & $\begin{array}{l}\text { Yöntem - Araştırma internet üzerinden çevrimiçi anket yöntemi ile } 419 \text { kişi ile gerçekleştirilmiştir. } \\
\text { Anketin birinci bölümünde bazı kişisel ve demografik bilgiler, ikinci bölümünde hizmet kalite ölçeği olan }\end{array}$ \\
\hline DINESERV & DINESERV, üçüncü bölümde ise müşteri vatandaşlık davranışı ölçeği yer almaktadır. Araştırmada elde \\
\hline $\begin{array}{l}\text { Yiyecek İçecek İşletmeleri } \\
\text { İstanbul }\end{array}$ & $\begin{array}{l}\text { edilen bulgular Cronbach Alfa, aritmetik ortalama, standart sapma, t-testi ve anova analizlerinden } \\
\text { yararlanılmıştır. Araştırmada hizmet kalitesi ve müşteri vatandaşlık davranışına ilişkin demografik } \\
\text { özelliklerin anlamlı bir etkisi olup olmadığını belirlemek için t-testi ve anova analizinden yararlanılmıştır. }\end{array}$ \\
\hline Gönderilme Tarihi 9 Eylül & $\begin{array}{l}\text { Son olarak iki kavram arasındaki ilişkiyi belirlemek için korelasyon analizi ile hizmet kalitesinin müşteri } \\
\text { vatandaşlık davranışı üzerindeki etkisini belirlemek için de regresyon analizinden yararlanılmıştır. }\end{array}$ \\
\hline $\begin{array}{l}2020 \\
\text { Revizyon Tarihi } 3 \text { Aralık } \\
2020\end{array}$ & $\begin{array}{l}\text { Bulgular - Araştırmada elde edilen bulgular sonucunda katılımcların hizmet kalitesine ilişkin algılarının } \\
\text { demografik özelliklere göre anlamlı bir farklılık olmadığı belirlenmiştir. Çalışmada elde edilen bulgular } \\
\text { doğrultusunda, hizmet kalitesinin müşteri vatandaşlık davranışı üzerinde anlamlı bir etkisi olduğu }\end{array}$ \\
\hline Kabul Tarihi 10 Aralık 2020 & $\begin{array}{l}\text { saptanmıştır }(\beta \mathrm{j}=0,892) \text {. Hizmet kalitesinin alt boyutları incelendiğinde katılımcıların en yüksek algıya } \\
\text { sahip olan boyut "fiziksel özellikler" }(\bar{x}=4,33) \text { olarak belirlenmiştir. }\end{array}$ \\
\hline $\begin{array}{l}\text { Makale Kategorisi: } \\
\text { Araştırma Makalesi }\end{array}$ & $\begin{array}{l}\text { Tartışma - Çalışma İstanbul'daki 1.sınıf restoran işletmeleri ile sınırlıdır. Daha sonraki araştırmalarda } \\
\text { farklı türde hizmet veren yiyecek içecek işletmelerinde gerçekleştirilebilir. Farklı türdeki işletmeler } \\
\text { arasında, müşteri vatandaşlık davranışlarının düzeyleri kıyaslanabilir. Ek olarak müşteri vatandaşlı } \\
\text { davranışı ile marka algısı, işletme imajı ya da örgütsel vatandaşlık davranışı arasındaki ilişkilerin de } \\
\text { araştırılması önerilmektedir. }\end{array}$ \\
\hline
\end{tabular}

\begin{tabular}{|c|c|}
\hline ARTICLE INFO & ABSTRACT \\
\hline Keywords: & $\begin{array}{l}\text { Purpose - In this research, it is aimed to determine the effect of service quality perceptions of individuals } \\
\text { who get service from 1st class restaurants in Istanbul on customer citizenship behavior. }\end{array}$ \\
\hline Behavior & \multirow{5}{*}{$\begin{array}{l}\text { Design/methodology/approach - The research was carried out with } 419 \text { people by using the internet } \\
\text { survey method. The first part of the questionnaire includes demographic information, the second part } \\
\text { includes the service quality scale DINESERV and the third part includes the scale customer citizenship } \\
\text { behavior. In the method part, Cronbach Alpha, arithmetic mean and standard deviation, t-test and one } \\
\text { way anova analysis. Finally, correlation analysis was performed to determine the relationship between } \\
\text { the two concepts and regression analysis to determine the effect of service quality on customer citizenship } \\
\text { behavior. }\end{array}$} \\
\hline Quality of Service & \\
\hline DINESERV & \\
\hline $\begin{array}{l}\text { Food and Beverage } \\
\text { Establishments }\end{array}$ & \\
\hline & \\
\hline Received 9 September 2020 & $\begin{array}{l}\text { Findings - In the research, t-test and ANOVA analysis were conducted to determine whether } \\
\text { demographic characteristics related to service quality and customer citizenship behavior had a significant } \\
\text { effect. As a result of these analyzes, it was determined that the participants' perceptions of service quality }\end{array}$ \\
\hline Revised 3 December 2020 & did not differ significantly according to demographic characteristics. In line with the findings obtained \\
\hline Accepted 10 December 2020 & $\begin{array}{l}\text { in the study, it was determined that service quality has a significant effect on customer citizenship } \\
\text { behavior }(\beta \mathrm{j}=0,892) \text {. Looking at the statistics of the service quality sub-dimensions, the dimension with } \\
\text { the highest average is "physical properties" }(\bar{x}=4,33) \text {. }\end{array}$ \\
\hline Article Classification: & Discussion - The research is limited to 1st class restaurant businesses in Istanbul. In subsequent research, \\
\hline Research Article & $\begin{array}{l}\text { it can be carried out in food and beverage businesses that provide different types of service. Levels of } \\
\text { customer citizenship behavior can be compared between different types of businesses. In addition, the } \\
\text { relationship between customer citizenship behavior and brand perception, business image or } \\
\text { organizational citizenship behavior can be examined. }\end{array}$ \\
\hline
\end{tabular}




\section{Giriş}

Hizmet sektörünün küreselleşmesi ve uluslararası ekonomi, hizmet şirketlerinin de kendilerini sürekli geliştirmelerini gerekli hale getirmektedir. Hizmet işletmeleri, rekabet gücünü artırmak için müşterilerin fikirlerine daha fazla önem vermeye başlamıştır. Aynı zamanda işletmelerde de hizmet pazarlaması müşterileri insan kaynakları olarak yönetmeye odaklanmaktadır (Bettencourt, 1997). Müşteri memnuniyeti konusunda standartların belirlenmesinde, müşteriler baskın sese sahiptir. Bunun yanı sıra müşteri memnuniyeti genellikle başarılı kalite yönetiminin öncelikli göstergesi haline gelmiştir. Böylece kalitenin tanımı, yine onu kullanacak olan kişiler tarafından paylaşılan fikirler ve kıstaslar ile oluşmaktadır (LengnickHall, 1996). Sunulan hizmetin birinci dereceden muhatabı olan müşteriler, hizmeti geliştirme ve daha nitelikli hale getirme konusunda işletmeler için geri bildirim kaynağı haline dönüşmektedir.

Müşterilerin, organizasyonel süreçte giderek artan rolleri ile 'kısmi çalışan' olarak görülmesi/kabul edilmesinde etkili olmaktadır. Bu nedenle işletmelerinde müşterilerin insan kaynaklarında etkili olabileceğinin farkında olması, bu süreci iyi yönetebilmesi için oldukça önemlidir (Groth, 2005). Müşteri gönüllü davranışı ve vatandaşlık ile ilgili literatür, kulaktan kulağa iletişim, işbirliği, katılım ve özgecilik gibi davranışların olumlu etkileri olduğu belirtilmektedir. Aynı zamanda müşteri vatandaşlık davranışının işletme performansını arttırdığı ve diğer müşterilere fayda sağladığı da belirtilmektedir (Fowler, 2013). Müşteri vatandaşlık davranışı özellikle işletmedeki işgücü maliyetini azaltmak ve üretkenliği arttırmak için hizmet sunumuna daha fazla katılımı teşvik etmektedir (Jung ve Yoo, 2017). İşletmelerin fırsatları değerlendirmesi veya var olan tehditlerden kaçınması için değerli kaynaklara sahip olması önemlidir. Nadir olan kaynaklar işletmelerin özgün stratejiler geliştirmesine ya da stratejilerini benzersiz şekilde uygulamalarına olanak sağlamaktadır. Bu bağlamda müşteriler tarafından sağlanan kaynaklar ise değerli, nadir bulunan ve çok az ikamesi olması, kaliteli ve rekabetçi sonuçlar sunabilmektedir. Etkili yönetimin ön koşullarından birisi olarak işletmeler müşteri kaynakları hakkında bilgi sahibi olmalıdır. Buna ek olarak bu kaynakların kalitesini sürekli olarak izlemelidirler (Lengnick-Hall, 1996). Bu nedenle işletmelerin müşteri kitlesini tanıması ve beklentileri hakkında bilgi sahibi olması kaliteli hizmet sunmasında katkı ve rehberlik etmektedir. Müşterilerin değişen beklentilerini takip eden işletmeler, kendi iş akışlarına bu doğrultuda ekleme ve çıarmalar yaparak müşteri memnuniyetinin devamlılığını sağlamış olacaktır. Vatandaşlık davranışı sergileyen müşteriler, gönüllü bir faaliyet zinciri başlatarak diğer müşterileri de aynı davranışları sergilemeye teşvik edebilmekte ve olumlu bir hizmet ortamında yüksek kalite sağlanabilmesine yardımcı olmaktadır (Yi, Gong ve Lee, 2013). Bilinen önemine rağmen müşteri vatandaşlık davranışına yer veren çalışmalar sınırlıdır. Bunun nedeni ise kavramın tam olarak anlaşılamaması ya da net olarak açıklanamamasıdır (Fowler, 2013). Bu çalışmadaki amaç da kavramın açıklanarak, yiyecek içecek işletmelerine sağlayacağı faydaların somut olarak tespit edilmesi ve literatüre kazandırılmasıdır.

\section{Kavramsal Çerçeve}

Kişiye ya da kuruluşlara sunulan hizmet, belirli bir bedel karşllığı satışa sunulur. Hizmetler herhangi bir mülkiyet oluşturmayan insanların veya insan gruplarının ihtiyaçlarını gidermek için gerçekleştirilen somut faaliyetleri kapsamaktadır (Doğan ve Tütüncü, 2003). Hizmetler fiziksel olarak var olmayan, müşteriye değer katmak için sergilenen davranışlardır (Angelova ve Zekiri, 2011). Kalite kavramı ise farklı çalışmalarda birbirinden farklı ifadeler ile tanımlanmaktadır. Kalite, kullanıcıların ihtiyaç ve beklentilerine göre şekillendiğinden dolayı sabit ve her alanda geçerli bir tanımı yapılamamaktadır. Kalite, müşteri beklentilerinin tam anlamıyla eksiksiz karşılanmasıdır (Şimşek, 2013). Parasuraman vd., (1985) tarafından kalite, "müşteri beklentilerinin giderilmesi", Crosby (1979) tarafından ise "ihtiyaçlara karşı uygunluk" olarak tanımlanmaktadır. Halis (2010), kaliteyi 'ürününüzde müşteriyi kendisine tutkun yapan sır' şeklinde ifade etmektedir. Bu doğrultuda hizmet kalitesi; tüketicilerin, tüketimden önce, tüketim sırasında ve sonrasında da değerlendirmeye aldığı birçok niteliği barındıran bir kavramdır (Bougoure ve Neu, 2010).

Hizmet sektörünün gelişmesi hem yerel hem de küresel çaptaki rekabeti arttırmaktadır. Bu durumda da somut ürünlerdeki gibi hizmet sektöründe de kalite pazarda var olabilmenin önemli unsuru haline gelmekte (Gelibolu ve Kerse, 2018) ve bu konuyu önemsemeyen işletmelerin yoğun rekabet ortamında zor duruma düşecekleri öngörülmektedir (Zengin ve Erdal, 2000). Tüketici beklentilerini karşılayan ya da beklentinin üzerinde sunulan hizmet kaliteli olarak nitelendirmektedir (Thorpe ve Summer, 2014). Bu sebeple kişilerin beklentileri farklı olacağından, kalite algılayışı da farklı şekillenecektir. Bu da hizmet kalitesinin birbirinden 


\section{N. Yarmac1 - E. Kefeli 12/4 (2020) 3947-3964}

farklı tanımlarının bulunmasına sebep olmaktadır. Hizmet kalitesi, tüketici ihtiyaçlarını ve beklentilerini karşılamaya yönelik yapılan hizmetlerdir (Meidute-Kavaliauskiene, Aranskis ve Litvinenko, 2014). İşletmelerde sunulan hizmetlerden tatmin olunmasının yanı sıra problemlere ve hizmete yönelik şikâyetlere sunulan çözümlerde kaliteye önem gösteren kurumların müşteri zihnindeki profilini olumlu yönde etkilemektedir. Çünkü hizmetin kullanıcıları olan müşteriler normal şartlarda değil de problemler karşısında çözüm sunulmasından daha hoşnut olmaktadır (Zengin ve Erdal, 2000). Hizmet kalitesinin değerlendirilmesi zordur, çünkü tüketici bir malı satın aldığı esnada kalite değerlendirmesi yaparken birden fazla somut ipucuna sahiptir; şekil, doku, renk, his, dış görünüş vb. fakat tüketici hizmeti satın aldığı esnada somut ipucu oldukça azdır. Genellikle somut unsurlar, hizmet alınan mekânın fiziksel yapısı ve hizmeti sunan personelin iletişimi ile sınırlı kalmaktadır (Parasuraman vd., 1985). Hizmet sunumlarında genellikle eş zamanlı üretim ve tüketim gerçekleştirilmektedir. Tüm bu karşılaşmalarda müşteriler tarafından hizmet kalitesi tecrübe edilerek değerlendirildiğinden ve bu değerlendirmeler her defasında tekrarlandığından yüksek öneme sahip olmaktadır (Lewis ve Mitchell, 1990).

Tüketicilerin istek ve ihtiyaçlarını karşılamak amacıyla üretilen hizmetin fiziksel bir yapısı bulunmamaktadır (Çelik, 2011). Her ne kadar hizmet kalitesi ürün kalitesi kadar kolay değerlendirilemese de bu konuda gerçekleştirilmiş çalışmalar ve geliştirilmiş ölçekler mevcuttur. Bu çalışmada kullanılacak olan DİNESERV ölçeği de yiyecek içecek işletmelerinde hizmet kalitesinin ölçümü için SERVQUAL (1985) ölçeğinden Steven vd. (1995), tarafından geliştirilmiştir. DINESERV ölçeğinin amacı, müşterilerin ihtiyaçlarına ve isteklerine göre ayarlanmış yiyecek içecek işletmelerinin hizmet kalitesini ölçerek restoran işletmelerine ve sahiplerine bilgi sağlamaktır (Bougoure ve Neu, 2010). DINESERV ölçeği ve alt boyutları (fiziksel özellikler, güvenirlik, heveslilik, güven telkin etme ve empati) hem yemek deneyiminin somut yönlerini hem de çalışan ve müşteriler arasındaki hizmet deneyiminin soyut yönlerini inceleme fırsatı sunmaktadır. Bu durum, kaynağı belirlenen sorunların düzeltilmesini daha kolay hale getirmektedir (Wakefield ve Blodge, 1999; Kim, Ng ve Kim, 2009).

Tüketicilerin restoran tercihlerinde oldukça fazla seçeneği bulunmakta ve bu nedenle artan kalite beklentileri ve sektörde yoğunlaşan pazar payları işletmeler için zorlu bir rekabet ortamı yaratmaktadır. Oluşan rekabet ortamında işletmeler kendilerini öne çıaracak farklı yollar arayarak fiziksel ortamlarda da bu yönde değişikliğe gitmektedir. Yöneticiler çeşitli pazarlama ve organizasyon hedeflerine hitap etmek için restoran tasarımı, düzen ve iç dekorasyonda farklılık yaratarak müşteri memnuniyetini arttıracak aynı zamanda çalışanların üretkenliğini kolaylaştıracak düzenlemeler de bulunmalıdır (Raajpoot, 2002). Hizmet kalitesinin yüksek olması tüketicilerin tekrar satın alma ve tavsiye etme niyetini de olumlu anlamda etkilemektedir (Şirin ve Aksu, 2016). Tüm bu literatür doğrultusunda yiyecek içecek işletmelerinde hizmet kalitesinin ölçülmesi işletme karlılığı ve sağlanan kalitenin devamlılı̆̆ için önemli hale gelmektedir.

Müşteri vatandaşlık davranışı da ilk olarak Groth (2005), tarafından 2005 yılında ortaya atılmıştır. Müşteri vatandaşlık davranışı aynı zamanda ekstra rol, müşteri gönüllü performansı, sosyal yanlısı davranış olarak daha önceki çalışmalarda kullanılmaktadır. Müşteri vatandaşlık davranışı hizmet kuruluşuna, hizmet çalışanlarına ve müşterilere karşı yönlendirilmiş yardımcı davranışlar olarak tanımlanmaktadır (Jeong ve Moon, 2009). Hem akademisyenlerden hem de sektördeki uygulama çalışmalarından büyük ilgi görerek hizmet araştırmalarında popüler hale gelmeye devam etmektedir (Bettencourt, 1997; Groth, 2005). Müşteri vatandaşlık davranışı doğrudan veya açıkça beklenmeyen ya da ödüllendirilmemiş davranışlardan oluşmaktadır. Daha yüksek hizmet kalitesinde bir araya gelebilecek ve hizmet işletmelerinin etkin işleyişini teşvik edebilecek bireysel, müşteri gönüllü davranışları olarak da tanımlanmaktadır (Groth, 2005). Müşteri

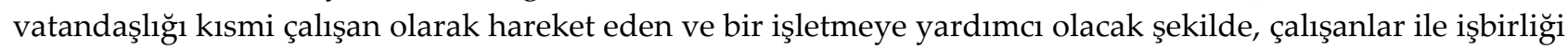
yapan, işletmeye fayda sağlayan müşterilerin, gönüllü davranışları olarak da tanımlanmaktadır (LengnicHall, 1996; Bettencourt, 1997). Müşteri vatandaşlık davranışının tanımlarındaki ortak temalar; gönüllülük, doğrudan bir ödülün olmayışı, bir işletmenin üretimi ve gelişimini destekleyici ve işletme performansını olumlu etkileyen çeşitli davranışlar olarak görülmektedir (Fowler, 2013).

Müşterilerin yapmakla yükümlü oldukları rol davranışları mal \hizmeti satın alma sürecinde kendisinden beklenen bedel \ödeme işlemlerini gerçekleştirmesidir. Bunun dışında gerçekleşen rol dışı davranışlar da gönüllü olarak gerçekleşmekte, karşılık beklemeden, işletme tarafından herhangi bir sınırlandırma ya da koşullandırma ile sergilenmeyen davranışlardır. Bu davranışlar hizmet veya mal satın alırken herhangi bir ön şart gerektirmezken işletmeye, çalışanlara ya da diğer müşterilere karşı sergilenen davranışları kapsamaktadır 


\section{N. Yarmac1 - E. Kefeli 12/4 (2020) 3947-3964}

(Türkmen, 2019). Örneğin, müşteriler olumlu deneyimlerini diğer potansiyel müşteriler ile paylaşabilmesi, sevdikleri mağazalarda alışveriş yapmak için daha uygun satış noktalarına gidebilmesi, hizmet çalışanlarına karşı iyi ve kibar davranışlar sergilemesi ve varsa sorunlarını paylaşabilmesidir (Bettoncourt, 1997). Müşteri vatandaşlık davranışı müşterilerin hizmeti satın alma sırasında ya da sonrasında hizmet ile ilgili gerçekleştirdikleri tüm rol dışı davranışları kapsamaktadır. Çalışanlarda olduğu gibi, hizmet sunumuna katılan müşterilerinde sergilemesi gereken rol içi davranışlar bulunmaktadır. Örneğin, çevrimiçi hizmetlerde bireyin kredi kartı ve adres bilgilerini doğru girmesi beklenmektedir. Bu davranışlar müşterinin sergilemesi gereken rol içi davranışlar olurken, işletmeyi başkalarına tavsiye etme ya da geri bildirim formu doldurma rol dışı davranış olarak değerlendirilmektedir (Groth, 2005). Müşteri vatandaşlık davranışı, örgütsel vatandaşlık davranışı ile benzerlik göstermektedir. Örgütsel vatandaşlık davranışında gönüllü davranışlar işletme çalışanları tarafından sergilenirken, müşteri vatandaşlık davranışında da müşteriler tarafından sergilenmektedir. Çalışan davranışı ve müşteri davranışı kavramları şekilsel olarak Tablo 1'de açıklanmaktadır. Tablo 1'de rol içi davranışlarda bulunan çalışanların iş yükümlülüklerinde tanımlanmış görevleri gerçekleştirdiği, rol içi davranışlarda bulunan müşterinin de hizmetin oluşmasında ortak yapım sürecine dâhil olduğu ifade edilmektedir. Örneğin, bir restoranda hizmet almak için gelen müşteri, hizmet sürecinin tamamlanabilmesi için menüden istediği yemeği seçerek bunu garsona bildirmekle yükümlüdür. Bu davranış hizmet sürecinin tamamlanabilmesi için müşterinin rol davranışıdır. Tablo 1'de son olarak da çalışanın sergilediği rol dışı davranışların örgütsel vatandaşlık davranışı, müşterinin sergilediği rol dışı davranışın ise müşteri vatandaşlık davranışı olduğu ifade edilmektedir. Bir restoranda hizmet alan müşteri bu işletmeyi yakınlarına tavsiye etmek ya da kalite formu doldurmak zorunda değildir. Müşteri bu davranışları kendi isteği ile yaptığı durumda vatandaşlık davranışı göstermiş olacaktır.

Tablo 1. Çalışan Davranışı ve Müşteri Davranışı Türleri

\begin{tabular}{ccc}
\hline Davranış Türü & Çalışan Davranışı & Müşteri Tutumu \\
\hline Rol-içi davranışlar & Tanımlanmış görevler & Müşteri ortak yapımı \\
\hline Rol-dışı davranışlar & Örgütsel vatandaşlık davranışı & Müşteri vatandaşlık davranışı \\
\hline
\end{tabular}

Kaynak: Groth, 2015.

Müşteri vatandaşlık davranışı ile örgütsel vatandaşlık davranışı bazı benzerlikler göstermektedir. İki kavramın da meydana gelebilmesi için performansların gönüllü ve tanımlanmış rol davranışlarının dışında gerçekleşmesi gerekmektedir. Yalnız müşteri vatandaşlık davranışının motivasyon kaynakları örgütsel vatandaşlık davranışından farklılık göstermektedir. Örgütsel vatandaşlık çerçevesi müşteriler için de genişletip uygulanarak, hizmet sunumlarında müşterilerin de rolü incelenmektedir. Farklı bir ifade ile rol içi davranışları, rol dışı davranışlardan ayıran örgütsel vatandaşlık davranışı teorisiyle tutarlı olarak müşterilerin rol içi davranışlarının benzer şekilde ayırt edilip edilemediği incelenmektedir (Groth, 2005). Tablo 2'de müşteri vatandaşlık davranışı kavramının öncesinde ve sonrasında literatürde yer alan benzer kavramlar tarihsel sira ile verilmektedir. 
Tablo 2. Müşteri Vatandaşlık Davranışı Ortak Kavram ve Tanımlar

\begin{tabular}{|c|c|c|c|}
\hline Kavram & Tanım & Boyut & Kaynak \\
\hline $\begin{array}{l}\text { Müşteri Gönüllü } \\
\text { Performansı }\end{array}$ & $\begin{array}{l}\text { İşletmelerin hizmet kalitesini sunma } \\
\text { becerilerini destekleyen, müşterilerin } \\
\text { faydalı isteğe bağlı davranışlarıdır. }\end{array}$ & $\begin{array}{l}\text { Önerilerde bulunma, Hizmet } \\
\text { karşılaşmalarında işbirliği, } \\
\text { Olumlu kulaktan kulağa } \\
\text { söylemler }\end{array}$ & $\begin{array}{l}\text { Bettencourt, } \\
\text { (1997) }\end{array}$ \\
\hline $\begin{array}{l}\text { Müşteri } \\
\text { Vatandaşlığı } \\
\text { Davranışı }\end{array}$ & $\begin{array}{l}\text { Hizmetin başarılı bir şekilde } \\
\text { üretilmesi ve sunulması için gerekli } \\
\text { olmayan ancak hizmet kuruluşlarına } \\
\text { yardımcı olan gönüllü } \\
\text { davranışlardır. }\end{array}$ & $\begin{array}{l}\text { Tavsiyede bulunmak, Diğer } \\
\text { müşterilere yardım etmek, } \\
\text { Organizasyona geri bildirim } \\
\text { sağlamak }\end{array}$ & $\begin{array}{l}\text { Groth, } \\
\text { (2005) }\end{array}$ \\
\hline $\begin{array}{l}\text { Müşteri Ekstra } \\
\text { Rol Davranışı }\end{array}$ & $\begin{array}{l}\text { Hizmet sunumu için gerekli } \\
\text { görülmeyen fakat sergilenmesi } \\
\text { işletmeler tarafından istenilen } \\
\text { davranıslardır. }\end{array}$ & $\begin{array}{l}\text { Öneride bulunma, Gönüllü } \\
\text { işbirliği, İşletme için çaba } \\
\text { gösterme }\end{array}$ & $\begin{array}{l}\text { Ahearne, } \\
\text { Bhattachary } \\
\text { a ve Gruen, } \\
(2005)\end{array}$ \\
\hline $\begin{array}{l}\text { Müşteri Örgütsel } \\
\text { Vatandaşlık } \\
\text { Davranışı }\end{array}$ & $\begin{array}{l}\text { Etkin organizasyon işleyişi için } \\
\text { müşteriler dışında organizasyonel } \\
\text { işleyiş için hizmet sunumunda } \\
\text { yardımcı gönüllü davranışlardır. }\end{array}$ & $\begin{array}{l}\text { Olumlu kulaktan kulağa } \\
\text { söylemler, İşletme } \\
\text { faaliyetlerine katılım, Esneklik, } \\
\text { yardımseverlik, Öneride } \\
\text { bulunma, Müşteri sesi, Diğer } \\
\text { müşterileri denetleme, }\end{array}$ & $\begin{array}{l}\text { Bove vd., } \\
\text { (2009) }\end{array}$ \\
\hline
\end{tabular}

Kaynak: Ferraz, 2018.

Tablo 2'de müşterilerin göstermiş olduğu gönüllü davranışların farklı başlık ve alt boyutlar ile incelendiği görülmektedir. Gelişen ve değişen rekabetçi iş ortamlarında vatandaşlık davranışlarına oldukça önem verilmektedir. Kuruluşun çalışanları gibi müşteriler de, özellikle hizmete dayalı kuruluşlarda çeşitli vatandaşlık davranışlarında bulunabilmektedir (Abolfathi, Tollabi ve Pourashrf, 2013).

Müşteri memnuniyeti ve müşteri vatandaşlık davranışı arasındaki bağlantı için teorik destek sosyal değişim teorisidir (Groth, 2005; Yi vd., 2013). Sosyal değişim bir etkileşim durumunda bireyler ve gruplar arasındaki kaynak alışverişini anlamaya çalışan sosyolojik bir teoridir (Ap, 1992). Farklı bir ifade ile sosyal değişim insanların başkalarından yararlandıklarında karşılıklı davranış veya eylemlere mecbur hissettikleri koşullar olarak da tanımlanmaktadır. Eğer bireyler örgütün vaatlerini yerine getirme derecesinden memnun ise kendilerinin de karşılıklı davranışlarda bulunma olasılıkları yüksektir. Bu nedenle kurumundan memnun çalışanların, kuruluşlarına veya iş arkadaşlarına karşı vatandaşlık davranışında bulunmaları daha olasıdır (Organ, 1988' den akt. Groth, 2005). Restoranlar sosyal ortamlar olarak önemli işlev göstermektedir. Bu nedenle kullanıcılar yemek yerken sosyal fayda da beklemektedir. Çalışanların müşterilere karşı daha dostane ve rahat bir ilişki içerisinde hizmet sağlamaları önemlidir. Örneğin çalışanlar müşteriler ile yakın ilişkiler kurmak için onların daha önce almış oldukları hizmet alışkanlıklarını hatırlayabilir, müşterilere isimleri ile hitap ederek müşteriler ile olan sosyal ilişkilerini güçlendirebilir (Lee, Choi, Kim ve Hyung, 2014). Bu gibi durumlarda müşteri vatandaşlık davranışının dayanağı olarak gösterilen sosyal değişim teorisi ortaya çıkabilir ve aldığı bu kaliteli hizmetin devamlılı̆̆ için müşteriler de aynı şekilde işletmeye ya da çalışanlara karşı ekstra rol davranışı gösterebilir.

Müşteri vatandaşlık davranışı birbirinden bağımsız çalışmalarda farklı alt boyutlarda incelenmiştir (Groth, 2005; Bove, 2008; Yi ve Gong, 2013; Yu-hong, Da-hai ve Shang-nan, 2013; Madani, Hosseini, Kordnaeji ve Isfahani, 2015). Groth (2005), bu kavramı ilk ortaya attığında müşteri vatandaşlık davranışını üç boyutta incelemektedir. Bu boyutlar; işletmeye geri bildirim sağlama, diğer müşterilere yardım etme ve işletmeyi başkalarına tavsiye etme şeklindedir. Bu araştırmanın ölçek kısmında faydalanılan Yi ve Gong (2013)'un 
çalışmasında ise müşteri vatandaşlık davranışının dört boyutu ele alınmaktadır. Ölçek geliştirme ve doğrulama adına yapılan bu çalışmada ele alınan boyutlar; işletmeye geri bildirim sağlama, işletmeyi başkalarına tavsiye etme, yardım severlik ve yapılan hataları tolere etmek şeklindedir.

- Geri Bildirim: İşletme müşterileri çalışanlara hizmet konusunda rehberlik etme ve öneri sunma konusunda eşsiz bir kaynak olmaktadır. Müşteriler sunulan hizmet hakkında büyük deneyime sahip olduğundan onlardan gelecek olan yorumlar önemli olmaktadır (Bettencourt, 1997). Müsşterilerden gelen bu geri bildirimler, işletme için çok değerli olmakta ve gönüllü olarak sergilendiğinden de ekstra rol davranışı oluşturmaktadır. Tüm bu davranışlar hizmet sunumunun tamamlanması için zorunlu eylemleri içermemektedir (Yi ve Gong, 2013).

- Tavsiye Etme: Hizmeti başkalarına önerme şeklinde gerçekleşir ve bir sadakat eylemi olarak görülmektedir (Chai, Malhotra ve Alpert, 2015). İşletme için olumlu olabilecek söylemlerin kulaktan kulağa ilerlemesi işletme için müşteri sadakatinin bir göstergesi olurken aynı zamanda işletmenin ürün ve hizmetlerinin tanıtımına fayda sağlamaktadır (Bettencourt, 1997).

- Yardımseverlik: Groth vd. (2014), bu boyutun işletmede hizmet alan müşterilerin, diğer müşterilere yardım etmek için sergilediği davranışları ifade ettiğini belirtmektedir. Burada yardım çalışandan çok müşteriye odaklanmaktadır (Yi ve Gong, 2013). Müşterilerin birbirleri ile olan iletişimleri, çalışanlara karşı dostça davranışları organizasyondaki işbirliği ve katılım davranışları işletme için faydalı olabilecek bir sosyal ağın oluşmasını sağlamaktadır (Bettencourt, 1997).

- Tolerans: Hizmet esnasında ortaya çıkan hatalar pazar payına ve işletme karlılığına zarar vererek, müşteri tercihlerini değiştirebileceğinden, bu ve benzeri durumlarda müşterilerin tolerans düzeylerinin önemli olduğu belirtilmektedir (Lengnick-Hall, 2000; Yi ve Gong, 20013). Bu boyut hizmet esnasında yaşanabilecek, hizmetin gecikmesi ya da ekipman eksikliği \arızası gibi sorunlar karşısında müşterilerin sabırlı olması ve bu duruma katlanmalarını ifade etmektedir.

Farklı sektörlerde müşteri vatandaşlık davranışını üzerine yapılan araştırmalarda kullanılan ölçeklerin alt boyutların da farklılık görülmektedir. Örneğin, bir restoran işletmesinde "tolere etme" davranışı sık görülürken bankacılık sektöründe bu davranış pek hoş karşılanmayabilir ve vatandaşlık davranışı olarak değerlendirilmeyebilir. Çünkü restoran hizmetlerinde yapılabilecek hatalar ufak olabilirken bankacılık hizmetlerindeki hatalar büyük maddi kayıplara sebep olabilir. Literatürde de farklı alt boyutlar ile müşteri vatandaşlık davranışını ele alan çalışmalar bulunmaktadır (Groth, 2005; Bove vd.; 2008; Jeong ve Moon, 2009; Yi ve Gong, 2013; Madani vd., 2015).

Müşterilerin gönüllü davranışlarını ortaya çıkaran net motivasyon kaynaklarını belirlemeye yönelik araştırmalar yapılsa da bunun zorluğuna dikkat çekilmektedir. Çünkü müşteriler, aynı anda birden fazla motivasyona sahip olabilmektedir (Batson ve Shaw, 1991). Ancak müşteri vatandaşlık davranışlarını ortaya çıkartan motivasyonları bilmek işletmelerin bu davranışlara kendi hedefleri doğrultusunda yön verebilmelerini sağlayacaktır (Türkmen ve Nardalı, 2017). Müşteri vatandaşlık davranışı örgütsel vatandaşlık davranışından doğmuş olsa da, müşterilerin motivasyon tabanı çalışanlarınkinden farklılık göstermektedir. Müşteriler, bir işletme tarafından istihdam edilmediği gibi çalışanların motivasyon kaynağ 1 olan ücret karşılığında; övgü, yüksek performans sergilemeleri veya diğer organizasyonel ödüllerden kaynaklanan davranışlar sergilemez (Groth, 2005). Davranışsal motivasyon; kişisel motivasyonu (durumlarda sergilenen kişisel tutumlar) ve sosyal motivasyonu (durumlara karşı sergilenen davranışlardaki sosyal destek) kapsamaktadır (Fisher vd., 2006). Buradan hareketle müşteriler kişisel normlar, ahlaki yükümlülükler ve bireysel değerler de dâhil olmak üzere belirli ilkelere sahip olduklarından müşteri vatandaşlık davranışı sergileyebilir (Choi ve Lotz, 2016). Müşteriler ile yakın ve etkili iletişim sırasındaki ilişkinin, müşterilerin hizmet sağlayıcısına karşı empati duygusunu arttırabileceği ve müşteri vatandaşlık davranışı ile sonuçlanan süreci teşvik edebileceği belirlenmiştir (Bove vd., 2008). Motivasyon teorisi, içsel ve dişsal motivasyonlara önem vererek şekillenmektedir (Fowler, 2013). İnsanlar iyi bir davranış sergilediklerinde iç mutluluğu elde eder ve bunu devam ettirmek ister. Bununla birlikte dişsal motivasyonlarda (takdir edilme, toplumda saygınlık) kişiyi bu tür davranışlara yönlendirebilmektedir (Kotler, 1994). Aynı zaman da müşteri vatandaşlık davranışı motivasyonlarını açıklamak için Maslow'un ihtiyaçlar hiyerarşisinden yararlanılmaktadır. Maslow'un hiyerarşi piramidine göre bireyin ihtiyaçları; fizyolojik ihtiyaçlar (nefes alma, beslenme), güvende olma ihtiyacı (beden, iş, aile, sağlık), ait olma (arkadaşlık, aile), saygınlık gereksinimi (özsaygı, özgüven) ve kendini gerçekleştirme (erdem sahibi, problem çözücü) şeklinde yukarı doğru ilerlemektedir. Buradan 


\section{N. Yarmac1 - E. Kefeli 12/4 (2020) 3947-3964}

hareketle yüksek düzeydeki ihtiyaçlar kişileri müşteri vatandaşlık davranışına yönlendirmektedir. Bu nedenle de müşterilerin özellikle hiyerarşik düzeyde öz saygı kazanmak için vatandaşlık davranışında bulundukları ya da bulunacakları varsayılmaktadır (Dewalska-Opitek ve Mitrega, 2019).

Hizmet kalitesi ve müşteri vatandaşlık davranışı kavramlarını tanımladıktan sonra bu iki kavram arasındaki ilişkiyi incelemek araştırmanın amacının kavranması için önemli olacaktır. Hizmet kalitesi müşteri memnuniyetinin öncüsü olmakta ve memnuniyette satın almayı olumlu anlamda etkilemektedir (Cronin ve Taylor, 1992). Müşterilerin satın alma niyetini etkileyen pek çok faktör olsa da en önemlisi algılanan kalite ve potansiyel müşteri ile işletme arasındaki ilişkidir. Ürün ve hizmet hakkında yeterince bilgiye sahip olmayan müşteriler karar vermek için imaj ve kalite özelliklerini dikkate almaktadır (Lengnick-Hall, 1996). Olumlu bir imaj işletme için bir avantaj sağlamakta, çünkü birçok açıdan işletmenin sunacağı hizmet hakkında müşteri algılarını etkilemektedir. İşletmenin müşteri zihninde olumlu bir imajı varsa küçük hatalar görmezden gelinebilirken tam tersi durumda da herhangi bir hata normalden fazla büyütülebilmektedir (Kang ve James, 2004). Hizmet kalitesi alt boyutlarından olan "fiziksel özellikler" burada öne çıkmaktadır. Örneğin restoran işletmesinde müşteriyi memnun etmek için sadece lezzetli bir yemek sunmak yeterli olmayacaktır. Aynı zamanda ortamın atmosferi, kokusu, müziğin sesi, personelin davranışları, ekipmanların temizliği vb. faktörlerde hizmet kalitesi değerlendirmesine dahil edilmektedir. Müşteriler kendilerini rahat hissetmedikleri bir yerde yemek yemeyi tercih etmeyebilir ve aldığı hizmeti olumsuz yorumlayabilir. Bu da onların vatandaşlık davranışı sergilemelerinin önüne geçebilmektedir. Müşterilerin algıladıkları hizmet kalitesini ölçmenin en faydalı yolu da yine müşteriye danışmaktır. Müşteri vatandaşlık davranışı alt boyutu olan "geri bildirim" de burada dikkat çekmektedir. İşletmeler müşterilerindeki vatandaşlık davranışını arttırabildikleri takdirde kişilerden hem olumlu hem de olumsuz durumların geri bildirimlerini alacaktır. Geri bildirim boyutu yöneticiler ve çalışanlar için oldukça önemlidir. Yöneticiler çalışanlar hakkında objektif bilgileri müşterilerden alarak gerekli durumlarda çalışanı ikaz ya da takdir edebilir. Böylece gelecekteki müşteri memnuniyetsizliklerinin önüne geçilerek aynı zamanda takdir görmüş çalışanın motive edilmesi sağlanmış olacaktır.

Yöneticiler müşterilere unutulmaz deneyimler kazandırmak için çaba göstermeli ve hizmet başarısızlı̆g 1 durumda, müşteri anında geri kazanılmalıdır (Agrawal ve Rahman, 2015). Hizmet kalitesindeki iyileştirmeler üretkenliği ve karlılığı arttırmakla beraber süreklilik de gerektirmektedir. İşletmelerin yapacak oldukları bu iyileştirmelerde kendilerini rakipleri ile kıyaslamak yerine onlardan kendi iş planlarına dahil edecekleri olumlu yönleri keşfetmeleri daha faydalı olacaktır (Edvardsson, 1998). Burada müşteri vatandaşlık davranışının etkisine vurgu yapmak önemlidir. Yöneticiler, müşterilerinin beklentilerini öğrenebilmek, işletmede bulunan ve artık güncel olmayan hizmetin farkına varabilmek için müşterilerden geri dönüş almak ister. Aynı şekilde işletmede yapılan yenilikleri yine var olan müşterileri aracıllı̆̆ ile potansiyel müşterilere iletebilir. Bu durum müşteri vatandaşlık davranışının "tavsiye etme" alt boyutu ile gerçekleşecektir. Vatandaşlık davranışı gelişmiş müşteriler memnun kaldıkları hizmeti etrafındaki insanlara da anlatacaktır. Böylece işletmelerde daha kısa yoldan yeni müşterilere ulaşabilirken tanıtım bültenlerine harcadıkları bütçelerde azalma sağlayabilecektir. Müşterileri tarafından hizmeti kolaylaştıracak hareketlerin sergilenmesi çalışanlarında daha iyi hizmet sunmaları üzerinde etkili olabilmektedir. Örneğin müşterilerin boş tabak \bardakları toplaması, siparişlerin masaya geldiği esnada çalışana yardım etmesi çalışanı da işini yapma konusunda motive etmektedir (Bove, 2011). Burada da hizmet kalitesi alt boyutlarından "empati" dikkat çekmektedir. Yöneticiler çalışanlarını daha yardımsever hizmet vermeleri konusunda eğittikleri takdirde müşterilerinde aynı şekilde çalışanlara karşı sempatik tavırlar sergilemesi beklenebilmektedir.

Müşterilerin hizmet çalışanlarından almış oldukları iyi hizmeti yönetime sunması çalışanları da oldukça memnun etmekte, öz güvenlerini arttırarak kendilerini değerli hissetmelerine olanak sağlamaktadır (Bove, 2011). Müşteri vatandaşlık davranışı boyutları arasında yer alan "geri bildirim" burada tekrar dikkat çekmektedir. Müşterilerin hem aldıkları hizmetin ve personelin kalitesini hem de herhangi bir sorun yaşadıklarında bunu işletmeye bildirmeleri önemlidir. İşletmelerin gözden kaçırdıkları aksaklıkları bilmesi farklı bir müşterinin de aynı problemi yaşamasının önüne geçecektir. Hizmet işletmelerinde müşteri beklentilerini etkileyen faktörler bulunmaktadır. Bunlar; kişilerin etrafındakiler ile iletişimleri, kişisel ihtiyaçları ve geçmiş deneyimleri olmaktadır (Parasuraman vd., 1985). Bu doğrultuda işletmeler müşterilerin zihinlerindeki hizmet kalite standartlarının üzerine çıkabilmek için çabalamalı ve en üst seviyede memnuniyeti amaçlamalıdır. 


\section{N. Yarmac1 - E. Kefeli 12/4 (2020) 3947-3964}

Bu çalışmanın amacı, İstanbul'da faaliyet gösteren Turizm İşletme Belgeli 1.Sınıf Restoranlardan hizmet alan müşterilerin hizmet kalite algısının müşteri vatandaşlık davranışı üzerindeki etkisini belirlemektir. Yiyecek içecek işletmelerinin sürekli bir rekabet içerisinde olduğu bilinmekte ve bu rekabet ortamı artarak devam etmektedir. Yeni bir kavram olan müşteri vatandaşlık davranışı da bu rekabet ortamında, müşterilerin aldıkları hizmetten memnun olmaları ya da beklentileri üzerinde bir hizmetle karşılaşmaları durumunda işletmeye fayda sağlayıcı gönüllü davranışlarını kapsamaktadır (Groth, 2005). Müşteri davranışlarının uzun vadeli ve dinamik etkilerini araştırmak işletmeler için aydınlatıcı ve yönetimsel strateji geliştirme konusunda da yararlı bilgiler sağlamaktadır (Yi ve Gong, 2013). Tüm bu literatür araştırmalarının doğrultusunda aşağıdaki ana hipotez ve alt hipotezler belirlenmiştir:

- Hizmet kalitesinin müşteri vatandaşlık davranışı üzerinde anlamlı bir etkisi vardır. (H)

- Hizmet kalitesinin güvenilirlik alt boyutunun, müşteri vatandaşlık davranışı üzerinde anlamlı bir etkisi vardir $\left(\mathrm{H}_{\mathrm{a}}\right)$.

- Hizmet kalitesinin heveslik alt boyutunun, müşteri vatandaşlık davranışı üzerinde anlamlı bir etkisi vardır $(\mathrm{Hb})$.

- Hizmet kalitesinin güven telkin etme alt boyutunun, müşteri vatandaşlık davranışı üzerinde anlamlı bir etkisi vardır $\left(\mathrm{H}_{\mathrm{c}}\right)$.

- Hizmet kalitesinin empati alt boyutunun, müşteri vatandaşlık davranışı üzerinde anlamlı bir etkisi vardır $\left(\mathrm{H}_{\mathrm{d}}\right)$.

- Hizmet kalitesinin fiziksel özellikler alt boyutunun, müşteri vatandaşlık davranışı üzerinde anlamlı bir etkisi vardır $\left(\mathrm{H}_{\mathrm{e}}\right)$.

\section{Yöntem}

Araştırmanın evrenini İstanbul'da bulunan Turizm İşletme Belgeli 1.Sınıf Restoranlarda hizmet alan müşteriler oluşturmaktadır. Araştırmada, ikincil veri yönteminden yararlanılarak İstanbul İl Kültür ve Turizm Müdürlüğünün web sayfasında 2019 yllına ait restoran işletmeleri ile ilgili istatistik bilgilerinden yararlanılarak İstanbul'da Turizm İşletme Belgeli 1.Sınıf Restoran olarak faaliyet gösteren 158 işletme isimleri ile birlikte belirlenmiştir (İstanbul İl Kültür ve Turizm Müdürlüğü, 2020). Bu işletmelerde hizmet alan müşterilerden 24607 sayılı, 8.12.2001 tarihli resmi gazetede yayınlanmış, Türk Medeni Kanunun 'Erginlik on sekiz yaşın doldurulmasıyla başlar.' şeklinde belirtilen 11.maddesince, kişilerin birey sayılması, hür iradelerini kullanabilmesi ve kazanç elde edebileceklerinden dolayı, 18 yaş üzerindeki bireylerin ankete katılması planlanmışır. Turizm Tesislerinin Belgelendirilmesine ve Niteliklerine İlişkin Yönetmelik, 21.06.2005 tarihli ve 25852 sayılı resmi gazete yayınlanmıştır. Bu yönetmeliğe göre lokantalar 1.Sınıf ve 2.Sınıf olarak sınıflandırılmıştır. Profesyonelleşme düzeyleri, diğer yiyecek içecek işletmelerine göre daha fazla olduğundan 1.Sınıf restoranlar evrenin, örneklemi olarak belirlenmiştir. Araştırmada örneklem belirlenirken olasılığa dayalı örneklem yöntemlerinden birisi olan tabakalı örnekleme kullanılmıştır. Tabakalı örnekleme homojen olmayan gruplar için kullanılmaktadır ve evrenin bütününü oluşturan gruplar, cinsiyet eğitim düzeyi, meslek, gelir düzeyi gibi farklı özelliklere göre sınıflandırılmaktadır (Kozak, 2018). Araştırmada kullanılan anket formu üç bölümden oluşmaktadır. Birinci bölümde, katılımcıların bazı kişisel ve demografik özellikleri, restoranlardan hizmet alma sıklıkları ve salgın (Covid19) sonrası yiyecek içecek işletmelerinden beklentilerini belirlemeye yönelik olmak üzere bir tane açık uçlu sorudan oluşmaktadır. İkinci bölümünde, Kılıç ve Kurnaz (2012) ile Kılıçhan ve Ülker (2015) tarafından Türkçe 'ye uyarlanan DINSERV ölçeklerinden yararlanılarak oluşturulan ölçek kullanılmıştır. Anket formunun üçüncü bölümünde ise, müşteri vatandaşlık davranışını ölçmek için Yi ve Gong'un (2013) geliştirdiği, Aracı ve Sezgin (2020) tarafından Türkçe' ye uyarlanan ölçek araştırma doğrultusunda düzenlenerek kullanılmıştır. Araştırma İstanbul Gedik Üniversitesi Rektörlüğünden, 20788822-050.01.04-76-E.164675 nolu etik kurul onayı doğrultusunda yürütülmüştür. 28 Nisan - 9 Temmuz 2020 tarihleri arasında gerçekleştirilmiştir. Toplam elde edilen 490 anketten 71 anketin evren ve örneklem kriterlerini karşılamadığı için çıkartılarak değerlendirmeye toplam 419 anket alınmıştır.

Katılımcıların profilini belirlenmek için yüzde ve frekans analizleri uygulanmıştır. Araştırmada, katılımcıların hizmet kalitesi algıları ile müşteri vatandaşlık davranış düzeylerinin bazı kişisel ve demografik özelliklerine göre anlamlı bir farklılı̆̆ gösterip göstermediğini tespit etmek için t-testi ve anova analizinden yararlanılmıştır. Hizmet kalitesi ile müşteri vatandaşlık davranışı ve alt boyutları arasındaki ilişkiyi belirlemek için korelasyon analizi yapılmıştır. Araştırmada bağımsız değişken olan hizmet kalitesinin, bağımlı 
değişken olan müşteri vatandaşlık davranışı üzerinde anlamlı bir etkisini belirlemek için basit doğrusal regresyon analizinden yararlanılmıştır.

\section{Bulgular}

Yiyecek içecek işletmelerinde hizmet alan müşterilerin aldıkları hizmet kalitesinin müşteri vatandaşlık davranışı üzerindeki etkisini belirlemeye yönelik gerçekleştirilen anket çalışmasına 419 kişi katılmıştır. Katılımcıların \%54,7'si kadın, \%45,3'ü ise erkeklerden oluşurken \%64,9'u bekâr, \%35,1'i ise evlidir. Katılımcıların eğitim durumlarına bakıldığında, \%0,7'si ilköğretim, \%11,2'si ortaöğretim, \%22,9'u ön lisans, $\% 49,9^{\prime}$ u lisans ve $\% 15,3$ 'ü de lisansüstü eğitime sahiptir. Yaş grubuna göre \%27'si 18-24 yaş, \%37'si 25-31 yaş, \%19,3'ü 32-38 yaş, \%10,5'i 39-45 yaş ve \%6,2'si ise 46-53 yaş aralığındaki katılımcılardan oluşmaktadır. Gelir durumu değişkenine bakıldığında ise katılımcıların; \%15,8'i 2100 TL veya altı, \%11,2'si 2101-2800 TL, \%11,9'u 28001-3500 TL, \%11,5'i 3501-4200 TL, \%12,6's1 4201-4900 TL ve \%37'si de 4901 TL veya üzerinde gelire sahip olduğu belirlenmiştir. Son olarak katılımcıların restoranlardan hizmet alma sıklıklarına bakıldığında \%37,7'si ayda bir defa, \%42,2'si haftada bir defa, \%16,'si haftada 2-3 defa ve \%4,1'i haftada 4 defadan fazla restoranlardan hizmet aldıkları tespit edilmiştir. Katılımcıların cinsiyete göre dağılımı yaklaşık olarak birbirine eşitken medeni duruma göre \%64, $9^{\prime}$ u bekâr katılımcılardan oluşmaktadır. Eğitim durumlarının büyük oranla lisans düzeyinde olduğu ve gelir düzeylerinin de büyük oranla 4901 TL veya üzerinde olduğu görülmektedir. Katılımcıların büyük bir bölümü de haftada bir defa dışarda yemek yemektedirler. Katılımcılara yöneltilen anket salgın (Covid19) döneminde gerçekleştirildiği için, bu dönemden sonra yiyecek içecek işletmelerinden beklentilerini belirlemek için açık uçlu bir soru da yöneltilmiştir. Bu soruya verilen cevapların özet hali Şekil 1'de yer almaktadır.

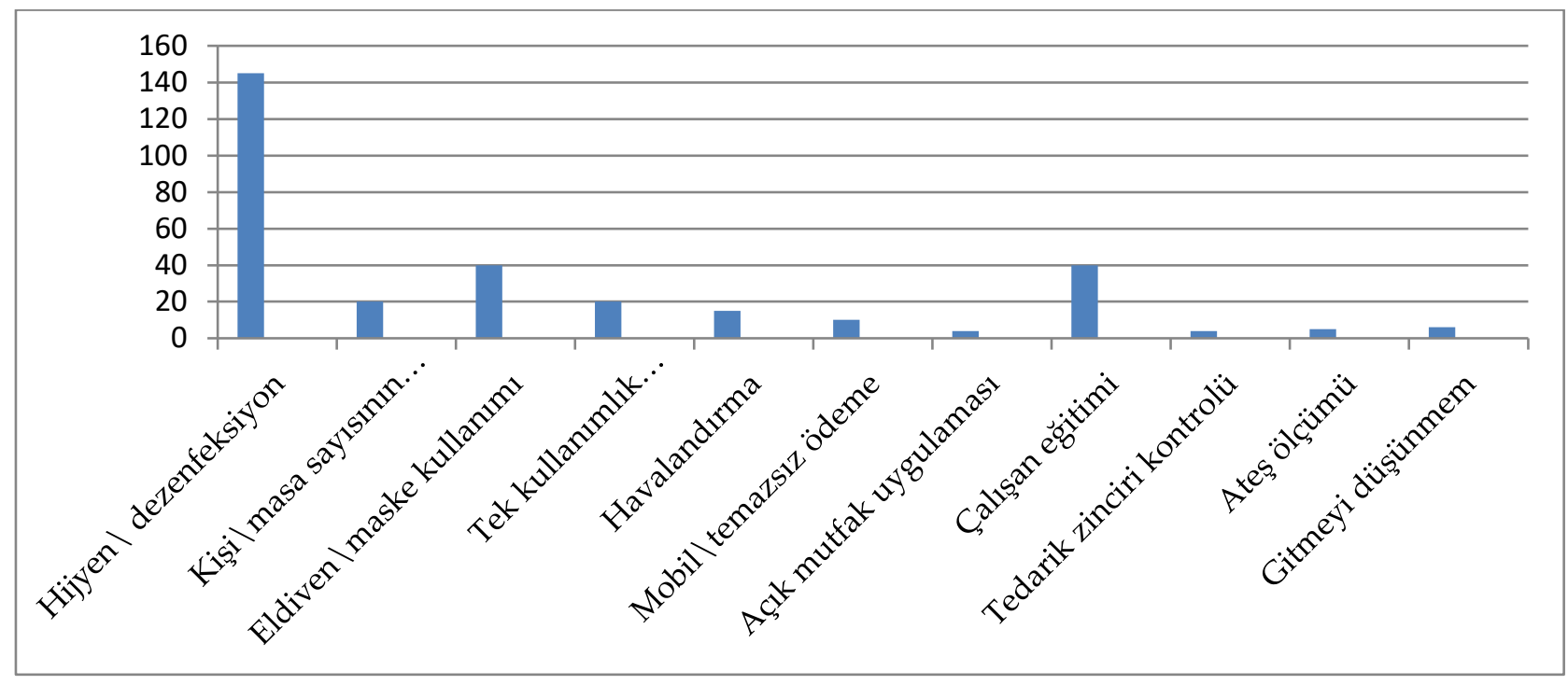

Şekil 1. Katılımcıların Korona Virüs (Covid-19) Salgını Sebebi İle Yiyecek İçecek İşletmeleri Tekrar Faaliyete Başladıklarında Yapması Gerekenler İle İlgili Görüşleri

Şekil 1'de "Korona virüs (Covid-19) salgını sebebi ile yiyecek içecek işletmeleri tekrar faaliyete başladıklarında güven ve kalite açısından neler yapmalıdır? Beklentilerinizi belirtiniz." sorusuna vermiş oldukları cevapların şekilsel hali sunulmaktadır. Ankette açık uçlu olarak bulunan bu sorunun cevaplanması katılımcıların inisiyatifine bırakılmıştır. Araştırmaya katılanların 308'i tarafından belirtilen görüşler 11 başlık altında kategorize edilmiştir. Katılımcıların cevaplarının büyük yoğunluğu hijyen ve dezenfeksiyon başlığı altında yer almakta ve işletmenin temizliğinin sık sık yapılması, ortak kullanım alanlarına fazladan önem gösterilmesi vurgulamaktadır. Devamında ise çalışanların maske ve eldiven kullanımı ile çalışan eğitimi katılımcılar tarafından vurgulanmıştır. Çalışanların buna özenle dikkat etmelerini, belirli aralıklar ile maske eldiven değişiminin yapılmasını, işletme yöneticilerinin bu anlamda çalışanına destek vermesi ve eğitim sağlamasını beklediklerini de belirtmişlerdir. Katılımcılar tarafından belirtilen görüşlerde en az bahsedilen konu ise açık mutfak uygulaması ve tedarik zinciri kontrolü olmaktadır. Katılımcıların az da olsa bir kısmı yöneltilen soruya belli bir süre yiyecek içecek işletmelerinden hizmet almayacakları yönünde cevap vermiştir. 


\section{N. Yarmac1 - E. Kefeli 12/4 (2020) 3947-3964}

Hizmet kalitesi ölçeğine ilişkin gerçekleştirilen faktör ve güvenilirlik analizindeki sonuçlara göre hizmet kalitesi ölçeğinde bulunan beş boyutun (fiziksel özellikler, güven telkin etme, empati, güvenilirlik ve heveslilik) toplam varyansı \%75,792'sini açıkladığı sonucuna ulaşılmıştır. Aynı zamanda hizmet kalitesi ölçeğine yönelik Cronbach's Alpha katsayıları incelendiğinde her bir boyutun 0,89 üzerinde olduğunu belirlenmiştir. Hizmet kalitesi ölçeğinin geneline ilişkin Cronbach's Alpha katsayısı ise 0,97 olarak hesaplanmıştır. Cronbach Alpha değerinin 0,60-0,80 arasında olması güvenilirliğin "iyi" 0,80-1,00 arasında olması da güvenilirliğin "yüksek" olduğunu ifade etmektedir (Kozak, 2018). Elde edilen bu değerler doğrultusunda ölçeğin güvenilir olduğu şeklinde yorumlamak mümkündür. Katılımcıların hizmet kalitesi algılarını belirlemeye yönelik ölçekte yer alan ifadeler değerlendirildiğinde, genel olarak görüşleri olumlu olmasına rağmen katılımcıların diğer ifadelere göre daha olumsuz algıya sahip oldukları ifadelerin "bu restoranda çalışanlar müşterilerin çıkarlarını savunmaktadır" ( $\overline{\mathbf{x}}=3,82)$ ve "bu restoranda çalışanlar, yöneticiler tarafından desteklenir" $(\overline{\mathbf{x}}=3,89)$ olduğu belirlenmiştir. Katılımcıların olumlu görüş belirttiği ifadeler ise "bu restoranda çalışanlar temiz, düzgün ve uygun bir şekilde giyinir" ( $\overline{\mathbf{x}}=4,46)$, "bu restoranın menüsü kolaylıkla okunabilir" ( $\overline{\mathbf{x}}=4,45)$ ve "bu restoranda yemek salonu oldukça temizdir" $(\overline{\mathbf{x}}=4,42)$ olduğu saptanmiştır.

Müşteri vatandaşlık davranışı ölçeğine ilişkin gerçekleştirilen faktör ve güvenilirlik analizindeki bulgular değerlendirildiğinde müşteri vatandaşlık davranışı ölçeğini oluşturan dört alt boyutun (yardımseverlik, tavsiye etme, tolerans ve geri bildirim) toplam varyansı \%84,864 oranında açıkladığı belirlenmiştir. Müşteri vatandaşlık davranışı ölçeğine ilişkin Cronbach's Alpha katsayıları incelendiğinde, her bir boyutun 0,84 üzerinde olduğu belirlenmiştir. Müşteri vatandaşlık davranışı ölçeğinin genel olarak Cronbach's Alpha katsayısı ise 0,93 olarak hesaplanmış ve bu değerler doğrultusunda ölçeğin güvenilir olduğunu yorumlamak mümkündür. Katılımcıların, müşteri vatandaşlık davranışına ilişkin en olumsuz görüş belirttikleri ifadelerin sırasıyla; "bu restoranda diğer müşterilere yardım ederim" ( $\overline{\mathbf{x}}=3,27)$ ve "bu restoranda diğer müşterilere tavsiyelerde bulunurum" ( $\overline{\mathbf{x}}=3,27)$ olduğu saptanmıştır. Katılımcıların en olumlu görüş belirttiği ifadeler ise sırasıyla; "bu restoranı arkadaşlarıma ve aileme tavsiye ederim" $(\overline{\mathbf{x}}=4,15)$, "bu restoranda bir sorunla karşılaştığımda çalışanlar ile paylaşırım" $(\overline{\mathrm{x}}=4,05)$ ve "bu restoran ve çalışanlarından olumlu bir şekilde bahsederim" ( $\overline{\mathbf{x}}=4,05)$ olduğu belirlenmiştir. Ölçek genelinde verilen ifadeler değerlendirildiğinde en olumlu görüş belirtilen ifadenin "arkadaşlarıma ve aileme tavsiye ederim" olduğu tespit edilmiştir. Belirlenen bu ifadenin işletmeler için oldukça faydalı olduğu ve kulaktan kulağa tanıtıma olanak sağladığı söylenebilmektedir. Tanıtım ve pazarlama için büyük emek ve bütçe ayıran işletmeler bunun bir yolunun da müşteriler olduğunu unutmamalı ve müşterilerine kaliteli hizmet sunarak bunun devamlılığını sağlamalıdır. Elde edilen bulgular da bunu destekler niteliktedir. Araştırmada kullanılan hizmet kalitesi ve müşteri vatandaşlık davranışı ölçeklerinin aynı zamanda bu ölçeklerin alt boyutlarına yönelik aritmetik ortalama ve standart sapma değerlerine Tablo 3 ve Tablo 4'te yer verilmektedir.

Tablo 3. Hizmet Kalitesi Ölçeğinin Alt Boyutlarına İlişkin Betimsel İstatistikler

\begin{tabular}{|l|c|c|}
\hline \multicolumn{1}{|c|}{ BOYUTLAR } & $\overline{\mathbf{x}}$ & s.s. \\
\hline Güvenirlik & 4,21 & 0,70 \\
\hline Heveslilik & 4,09 & 0,83 \\
\hline Güven Telkin Etme & 4,15 & 0,79 \\
\hline Empati & 4,00 & 0,84 \\
\hline Fiziksel Özellikler & 4,33 & 0,67 \\
\hline HízMET KALİTESİ & $\mathbf{4 , 1 8}$ & $\mathbf{0 , 6 8}$ \\
\hline
\end{tabular}

Tablo 3'de hizmet kalitesi ölçeğinin betimsel analizleri incelendiğinde katılımcıların ifadelere olumlu olarak katılım gösterdikleri saptanmıştır $(\overline{\mathrm{x}}=4,18)$. Hizmet kalite ölçeğinin alt boyutlarına ilişkin bulgular incelendiğinde ise katılımcıların en olumlu düzeyde katılım gösterdikleri alt boyutun "fiziksel özellikler" $(\overline{\mathrm{x}}=4,33)$ olduğu tespit edilmiştir. Hizmet kalitesinin alt boyutlarına yönelik bulgularda, katılımcıların diğer alt boyutlara göre daha olumsuz düzeyde görüş bildirdikleri alt boyutun ise "empati" $(\overline{\mathrm{x}}=4,00)$ alt boyutu olduğu belirlenmiştir. Araştırma sonucunda elde edilen bulgular ele alındığında, hizmet kalitesinin alt boyutlarına ilişkin katılımcı görüşlerin olumlu yönde olduğu saptanmıştır. 
N. Yarmac1 - E. Kefeli 12/4 (2020) 3947-3964

Tablo 4. Müşteri Vatandaşlık Davranışı Ölçeğinin Boyutlarına İlişkin Betimsel İstatistikler

\begin{tabular}{lccc}
\hline & BOYUTLAR & $\overline{\mathbf{x}}$ & s.s. \\
\hline Geri Bildirim & 3,79 & 0,92 \\
\hline Tavsiye Etme & 4,06 & 0,90 \\
\hline Yardımseverlik & 3,36 & 1,13 \\
\hline Tolerans & 3,57 & 1,09 \\
\hline MÜŞTERI VATANDAŞLIK DAVRANIŞI & $\mathbf{3 , 6 7}$ & $\mathbf{0 , 8 5}$ \\
\hline
\end{tabular}

Tablo 4'te müşteri vatandaşlık davranışı ölçeğine yönelik katılımcıların olumlu ifadeler belirttikleri görülmektedir ( $\overline{\mathrm{x}}=3,67)$. Müşteri vatandaşlık davranışı alt boyutlarına yönelik belirtilen ifadelerin ortalamaların incelediğimizde en olumsuz düzeyde görüş belirtilen alt boyutun "yardımseverlik" $(\overline{\mathrm{x}}=3,36)$ alt boyutu olduğu dikkat çekmektedir. En olumlu düzeyde katılım gösterilen alt boyut ise "tavsiye etme" ( $\bar{x}=4,06)$ boyutu olduğu sonucuna ulaşılmıştır.

Araştırmada katılımcıların hizmet kalitesi algılamalarının ve müşteri vatandaşlık davranışı düzeylerinin demografik özelliklere göre anlamlı bir farklılık gösterip göstermediğini belirlemek için t-testi ve anova analizi yapılmıştır. Bu analizler sonucunda katılımcıların hizmet kalitesine ve müşteri vatandaşlık davranışına ilişkin yaş, cinsiyet, medeni durum, gelir durumu, eğitim düzeyi ve restoranlardan hizmet alma sıklıklarında 0,05 anlamlılık düzeyinde bir farklılık olmadığı belirlenmiştir. Hizmet kalitesi ve müşteri vatandaşlık davranışı ile alt boyutları arasındaki ilişkinin belirlemesine yönelik korelasyon analizi sonuçlarına Tablo 5 'te yer verilmektedir.

Tablo 5. Hizmet Kalitesi ve Müşteri Vatandaşlık Boyutları İlişkisine Yönelik Korelasyon Katsayıları

\begin{tabular}{|c|c|c|c|c|c|c|}
\hline BOYUTLAR & & $\begin{array}{c}\text { Müşteri } \\
\text { Vatandaşlık } \\
\text { Davranışı }\end{array}$ & Geri Bildirim & Yardımseverlik & Tavsiye Etme & Tolerans \\
\hline \multirow{2}{*}{$\begin{array}{l}\text { Hizmet } \\
\text { Kalitesi }\end{array}$} & $\mathrm{r}$ & 0,711 & 0,561 & 0,489 & 0,791 & 0,602 \\
\hline & $\mathrm{p}$ & $0,000^{* * * *}$ & $0,000^{* * * *}$ & $0,000^{* * * *}$ & $0,000^{* * *}$ & $0,000^{* * * *}$ \\
\hline \multirow{2}{*}{ Güvenilirlik } & $\mathrm{r}$ & 0,599 & 0,518 & 0,357 & 0,716 & 0,506 \\
\hline & $\mathrm{p}$ & $0,000^{* * *}$ & $0,000^{* * * *}$ & $0,000^{* * * *}$ & $0,000^{* * *}$ & $0,000^{* * * *}$ \\
\hline \multirow{2}{*}{ Heveslik } & $\mathrm{r}$ & 0,660 & 0,513 & 0,463 & 0,739 & 0,551 \\
\hline & $p$ & $0,000^{* * * *}$ & $0,000^{* * * *}$ & $0,000^{* * * *}$ & $0,000^{* * * *}$ & $0,000^{* * * *}$ \\
\hline \multirow{2}{*}{$\begin{array}{l}\text { Güven Telkin } \\
\text { Etme }\end{array}$} & $\mathrm{r}$ & 0,664 & 0,518 & 0,439 & 0,768 & 0,566 \\
\hline & $\mathrm{p}$ & $0,000^{* * * *}$ & $0,000^{* * * *}$ & $0,000^{* * * *}$ & $0,000^{* * *}$ & $0,000^{* * * *}$ \\
\hline \multirow{2}{*}{ Empati } & $\mathrm{r}$ & 0,704 & 0,530 & 0,512 & 0,740 & 0,614 \\
\hline & $\mathrm{p}$ & $0,000^{* * * *}$ & $0,000^{* * * *}$ & $0,000^{* * * *}$ & $0,000^{* * *}$ & $0,000^{* * * *}$ \\
\hline \multirow{2}{*}{$\begin{array}{c}\text { Fiziksel } \\
\text { Özellikler }\end{array}$} & $\mathrm{r}$ & 0,613 & 0,482 & 0,442 & 0,662 & 0,510 \\
\hline & $\mathrm{p}$ & $0,000^{* * * *}$ & $0,000^{* * * *}$ & $0,000^{* * * *}$ & $0,000^{* * * *}$ & $0,000^{* * * *}$ \\
\hline
\end{tabular}

${ }^{*} \mathrm{p}<0,05{ }^{* * *} \mathrm{p}<0,001$

Hizmet kalitesi ve alt boyutları ile müşteri vatandaşlık davranışı ve alt boyutlarının ilişkisini belirlemek için korelasyon analizi Tablo 5'te verilmektedir. Hizmet kalitesi ve müşteri vatandaşlık davranışı arasında anlamlı düzeyde kuvvetli bir ilişki olduğu saptanmıştır $(\mathrm{r}=0,711)$. Hizmet kalitesinin müşteri vatandaşlık davranışının alt boyutları olan geri bildirim $(r=0,561)$, yardımseverlik $(r=0,486)$, tavsiye etme $(r=0,791)$ ve tolerans $(r=0,602)$ ile ilişkisine bakıldığında orta düzeyin üzerinde anlamlı bir ilişki olduğu saptanmıştır. "Tavsiye etme" $(r=0,791)$ alt boyutu ile hizmet kalitesi arasında da kuvvetli düzeyde anlamlı bir ilişki olduğu saptanmaktadır.

Korelasyon katsayılarını incelendiğinde hizmet kalitesi alt boyutları güvenilirlik $(r=0,599)$, fiziksel özellikler $(\mathrm{r}=0,613)$, heveslilik $(\mathrm{r}=0,660)$, güven telkin etme $(\mathrm{r}=0,664)$ ve empati $(\mathrm{r}=0,704)$ ile müşteri vatandaşlik davranış1 arasında orta düzeyin üzerinde anlamlı bir ilişki olduğu sonucuna ulaşılmıştır. En yüksek değere sahip olan hizmet kalitesi alt boyutu ise "empati" ( $\mathrm{r}=0,704)$ müşteri vatandaşlık davranışı ile kuvvetli düzeyde anlamlı bir ilişkiye sahiptir. Hizmet kalitesinin müşteri vatandaşlık davranışı üzerindeki etkisini belirlemek için yapılan basit doğrusal regresyon analizi ve hizmet kalitesi alt boyutlarının müşteri vatandaşlık davranışı üzerindeki etkilerini belirlemek için çoklu doğrusal regresyon analizleri Tablo 6 ve Tablo 7 'de verilmektedir. 
N. Yarmac1 - E. Kefeli 12/4 (2020) 3947-3964

Tablo 6. Hizmet Kalitesinin Müşteri Vatandaşlık Davranışı Üzerindeki Etkisi

\begin{tabular}{lcccccc}
\hline Bağımsız Değişkenler & $\boldsymbol{\beta} \mathbf{j}$ & $\mathbf{S}(\mathbf{b j})$ & $\mathbf{t}$ & $\mathbf{p}$ & $\mathbf{F}$ & $\mathbf{p}$ \\
\hline Sabit & $-0,068$ & - & $-0,369$ & 0,712 & \multirow{2}{*}{426,703} & \multirow{2}{*}{$0,000^{* * * *}$} \\
\hline Hizmet Kalitesi & 0,892 & 0,711 & 20,657 & $0,000^{* * * *}$ & & \\
\hline
\end{tabular}

"p<0,05 *** $p<0,001$

Tablo 6'da hizmet kalitesinin genel olarak müşteri vatandaşlık davranışı üzerindeki etkisini belirlemeye yönelik basit doğrusal regresyon analizine ilişkin bulgular verilmektedir. Analiz sonuçları incelendiğinde hizmet kalitesinin müşteri vatandaşlık davranışı üzerinde kuvvetli düzeyde anlamlı bir etkisi olduğu sonucuna ulaşılmıştır $(\mathrm{F}=426,703 \mathrm{p}<0,001)$. Hizmet kalitesinin müşteri vatandaşlık davranışı üzerindeki etkisini belirlemeye yönelik yapılan analizde hizmet kalitesinde gerçekleştirilen 1 birim artışın, müşteri vatandaşlık davranışı üzerinde 0,892'lik bir artış yaratacağı saptanmıştır.

Tablo 7.Hizmet Kalitesi Alt Boyutlarının Müşteri Vatandaşlık Davranışı Üzerindeki Etkileri

\begin{tabular}{lcccccc}
\hline Bağımsız Değişkenler & $\boldsymbol{\beta} \mathbf{j}$ & $\mathbf{S}(\mathbf{b j})$ & $\mathbf{t}$ & $\mathbf{p}$ & $\mathbf{F}$ & $\mathbf{p}$ \\
\hline Sabit & 0,246 & - & 1,222 & 0,222 \\
\hline Güvenirlik & 0,025 & 0,020 & 0,314 & 0,754 \\
\hline Heveslilik & 0,175 & 0,171 & 2,275 & $0,023^{*}$ \\
\hline Güven Telkin Etme & 0,061 & 0,057 & 0,675 & 0,500 & & \\
\hline Empati & 0,398 & 0,393 & 5,195 & $0,000^{* * * *}$ \\
\hline Fiziksel Özellikler & 0,174 & 0,138 & 2,531 & $0,012^{*}$ & & $0,000^{* * *}$ \\
\hline
\end{tabular}

${ }^{*} \mathrm{p}<0,05{ }^{* * *} \mathrm{p}<0,001$

Tablo 7'de hizmet kalitesi alt boyutlarının müşteri vatandaşlık davranışı üzerindeki etkileri belirlemek için çoklu doğrusal regresyon analizi sonuçları verilmektedir. Bulgular incelendiğinde hizmet kalitesi alt boyutlarından heveslilik, empati ve fiziksel özelliklerin müșteri vatandaşlık davranışı üzerinde kuvvetli düzeyde anlamlı bir etkisinin olduğu belirlenirken güvenirlik ve güven telkin etme boyutlarının anlamlı bir etkisi olmadığı saptanmıştır ( $\mathrm{f}=91,052 \mathrm{p}<0,001)$.

\section{Sonuç ve Tartışma}

Hizmet işletmelerinde karlılı̆̆ arttırmak ve pazarda belli bir paya sahip olmak için işletmeler birbirinden farklı çalışmalar yapmaktadır. Son zamanlarda da bu çalışmalar müşteriler üzerinde yoğunlaşarak müşterinin sesine de kulak verilmektedir. Müşteri sadece hizmetin sunulacağı kişi değil aynı zamanda hizmetler üretilirken bunun da bir parçası olmaktadırlar. Bu nedenle işletmelerin kendi standartlarını arttırmak için yapacakları çalışmalarda müşterilerinin fikirlerine ve düşüncelerine başvurmaları daha gerçekçi veriler elde etmelerine olanak sağlamaktadır. Hizmet kalitesinin müşteri vatandaşlık davranışı üzerindeki etkilerini belirlemek üzere, İstanbul' daki 1.Sınıf Restoranlarda hizmet alan bireyler ile yapılan bu çalışmanın sonuçları özetle şu şekilde verilebilir;

Hizmet kalitesi ölçeğine yönelik bulgular değerlendirildiğinde en olumlu görüş belirtilen ifadeler "fiziksel özellikler" alt boyutu içerisinde yer almaktadır. Buradan da anlaşılabileceği üzere işletmelerin yaratmış olduğu görüntü, atmosfer hizmet kalite algısında da olumlu etkiye sebep olabilmektedir. Hizmetlerin soyut yapıda olduğunu literatür kısmında belirtilmiş bu nedenle hizmet üreticisi işletmeler müşterilerin zihinlerinde olumlu anlamda imaj yaratabilmek için hizmeti somutlaştırma ihtiyacı güderler. Ladhari vd., (2008) restoranlarda bulunan somut iletişim araçlarının da son derece çekici temiz ve konforlu olması gerektiğini belirterek, bu araçların müşteri ile kurulan iletişimin birer parçası olduğunu savunmaktadır. Katılımcıların hizmet kalitesine yönelik en düşük düzeyde görüş bildirdikleri "empati" $(\bar{x}=4,00)$ alt boyutu olmuştur. Kılıçhan ve Ülker'in (2015) çalışmasının sonuçlarına göre de hizmet kalitesi alt boyutlarından en yüksek ortalamaya "fiziksel özellikler" sahip olduğundan bu çalışma ile paralellik göstermektedir. Bu çalışmada hizmet kalitesi alt boyutlarında en düşük düzeyde görüş "empati" alt boyutu olurken Kılıç ve Kurnaz'ın (2012) çalışmalarında ise "empati" en yüksek düzeyde görüş bildirilen alt boyutu sonucuna ulaşılmıştır. Çalışma sonuçları bazı çalışmalar ile de farklı sonuçlar göstermektedir; Bilgin ve Kethüda (2017), "heveslilik" Kılıç ve Kurnaz (2012) ise "empati" alt boyutlarının en yüksek değerde olduğunu saptamışlardır. Çalışmalar arasındaki bu farklılıkların sebebi, hem üretimde hem de tüketimde büyük oranda insan 
faktörünün yer almasından kaynaklandığı şeklinde yorumlanabilir. Hizmet işletmelerinde bulunan müşterilerin ihtiyaç ve beklentileri sürekli olarak değişiklik gösterdiğinden farklı sonuçlar elde edilebilmektedir. Müşterilerin ihtiyaç ve beklentilerinin sürekli olarak değişmesi hizmet kalitesinde standardizasyonun önüne geçebilmektedir. Bu nedenle işletmeler müşteri beklentilerini sürekli takip ederek bu dezavantajı ortadan kaldırmaya çalışmalıdır.

Katılımcıların müşteri vatandaşlık davranışına ilişkin ifadelerinde bu davranışının ortalama düzeyde $(\bar{x}=3,67)$ olduğu saptanmıştır. Müşteri vatandaşlık davranışı alt boyutlarına yönelik yapılan analizlerde en olumsuz düzeyde görüş belirtilen alt boyut "yardımseverlik" $(\overline{\mathrm{x}}=3,36)$ olmaktadır. Bu sonuç, Aracı ve Sezgin'in (2020) çalışması ile de paralellik göstermektedir. En olumlu düzeyde katılım gösterilen alt boyut ise "tavsiye etme" ( $\overline{\mathrm{x}}=4,06)$ boyutu olduğu sonucuna ulaşılmıştır. Mosavi ve Ghaedi $(2012)$, hizmetten memnun müşterilerin olumlu kulaktan kulağa iletişimle faydalı bilgileri diğer potansiyel müşteriler ile paylaşarak, kuruluşun pazarlama araştırmalarına destek sağlamak gibi etkileri olduğunu belirtmektedir. Genel olarak değerlendirildiğinde tavsiye etme boyutu işletmeler için önemli olacaktır. Çünkü müşterilerin memnun kaldıkları hizmet hakkında etrafındaki kişileri bilgilendirmesi bir anlamda o işletmenin reklamını yapması anlamına gelmektedir. Hizmet işletmelerinin tanıtım ve pazarlama bültenleri için belirli bütçeler ayırmaktadırlar. Çalışmanın sonuçlarına göre işletmeler kaliteli bir hizmet sunduğu takdirde tanıtım faaliyetlerini daha kolay ve etkili bir şekilde sağlayabilmektedir.

Hizmet kalitesi ve müşteri vatandaşlık davranışı arasındaki ilişkiyi belirlemek üzere yapılan korelasyon analizinde iki değişken arasında kuvvetli düzeyde anlamlı bir ilişki olduğu belirlenmiştir $(r=0,711)$. Yi ve Gong'un (2006), çalışmalarında da müşteri vatandaşlığı davranışı ile algılanan hizmet kalitesi arasında pozitif ve anlamlı bir ilişki tespit edilmiş, müşteriler tarafından algılanan hizmet kalitesinin müşteri davranışlarından da etkilediğini belirtmişlerdir. Hizmet kalitesinin müşteri vatandaşlık davranışı alt boyutları arasında en kuvvetli düzeyde anlamlı ilişkisi ise "tavsiye etme" $(\mathrm{r}=0,791)$ en zayıf ilişkisi ise "yardımseverlik" $(\mathrm{r}=0,489)$ olduğu tespit edilmiştir. Bu sonuçla benzer olarak literatürde çalışmalar bulunmaktadır. Nagy ve Marzouk (2018), çalışmalarında en yüksek ilişkinin memnuniyet ve sadakat arasında olduğunda belirlemişlerdir. Restoran hizmetleri için bakıldığında da, restoranın tanınırlığını ve saygınlığını arttırmada pek çok yöntem bulunurken, hizmet ile alakalı bir müşteriden diğer müşteriye gelen tavsiye davranışı, potansiyel müşterilerin restoran tercihlerinde etkili olabilmektedir (Aracı ve Sezgin, 2020). Hizmet kalitesinin müşteri vatandaşlık davranışının alt boyutlarından "tavsiye etme" ile olan kuvvetli düzeydeki ilişkisi bize müşterilerin memnun kaldıkları hizmeti etrafı ile paylaştıklarını açıklamaktadır. Bu davranış işletmelerin oldukça olumlu kabul edecekleri ve farklı insanlara ulaşmalarında kolaylık sağlayacak bir davranış şeklidir. Müşteri vatandaşlık davranışı ile de hizmet kalitesi alt boyutları arasındaki korelasyon analizine baktığımızda en kuvvetli ilişki "empati" ( $\mathrm{r}=0,704)$ alt boyutu en zayıf ilişki ise "güvenilirlik" ( $\mathrm{r}=0,599)$ alt boyutu olduğu belirlenmiştir.

Korelasyon katsayılarından anlaşılacağı üzere kaliteli hizmet alan müşteriler işletmeye karşı olumlu davranışlar sergilemekte ve bunu herhangi bir beklentiye girmeden yapmaktadırlar. Hizmet kalitesinin müşteri vatandaşlık davranışının alt boyutlarından olan "tavsiye etme" ile olan kuvvetli düzeydeki ilişkisi, müşterilerin memnun kaldıkları hizmeti etrafı ile paylaştıklarını açıklamaktadır. Bu davranış işletmelerin oldukça olumlu kabul edecekleri ve farklı insanlara ulaşmalarında kolaylık sağlayacak bir davranış şeklidir. Aynı zamanda işletmeye hizmet almak için gelen müşteriler çalışanlar tarafından empati duygusunu hissettiklerinde müşteri vatandaşlık davranışı gösterme eğiliminde bulunmaktadırlar. Farklı bir ifade ile çalışan tarafından ekstra iyi hizmet alan müşteri aynı şekilde çalışan için kendisi de ekstra davranış gösterebilmektedir. Burada literatür kısmında bahsettiğimiz "sosyal değişim teorisini" desteklemektedir.

Hizmet kalitesinin müşteri vatandaşlık davranışı üzerindeki etkisini belirlemeye yönelik basit doğrusal regresyon analizi uygulanmıştır. Elde edilen analizlere göre hizmet kalitesinde gerçekleşen 1 birimlik artış müşteri vatandaşlık davranışı üzerinde 0,892'lik etkiye sebep olmaktadır. Farklı bir ifade ile de hizmet kalitesinin müşteri vatandaşlık davranışı üzerinde binde birde bile anlamlı bir etkisi görülmektedir. Hizmet kalitesinin müşteri vatandaşlık davranışı üzerinde etkisi olduğu tespit edilmektedir. Regresyon analizi doğrultusunda araştırmanın temel hipotezi olan "Hizmet kalitesinin müşteri vatandaşlık davranışı üzerinde anlamlı bir etkisi vardır." hipotezi desteklenmiştir. Dolayısıyla hizmetten memnun kalan müşteriler, işletmeye fayda sağlayıcı davranışlar sergilemektedir. Aynı zamanda hizmet kalite boyutları ile müşteri memnuniyeti arasındaki anlamlı ilişkinin kanıtlandığı çalışmalarda mevcuttur. Şahin ve Şen (2017), hizmet işletmesinde müşterilerin kalite algılamaları üzerinde fiziksel özellikler, güven, güvenilirlik, empati ve hevesliliğin pozitif 


\section{N. Yarmac1 - E. Kefeli 12/4 (2020) 3947-3964}

yönde etkisi olduğunu belirtmektedirler. Chen, Hsieh, Chang ve Chen (2015), yaptıkları çalışmada gıda blog kullanıcılarının hizmetten memnun kaldıkları takdirde müşteri vatandaşlık davranışına katılmaya istekli olduklarına ve psikolojik ihtiyaçlarının karşılanmasının müşteri vatandaşlık davranışı üzerinde de doğrudan pozitif etkisi olduğunu saptamaktadırlar. Gelibolu ve Kerse'de (2018) yaptıkları çalışmada hizmet kalitesinin müşteri vatandaşlık davranışı üzerindeki etkisinin olumlu olduğunu saptamıştır. Regresyon analizlerinden anlaşıldığı üzere kaliteli hizmet, müşterilerin vatandaşlık davranışı üzerinde olumlu etkiye sahip olmaktadır. İstanbul'daki 1.sınıf restoranlar müşterilerine sunduğu kaliteli hizmet ile hem müşteri memnuniyetini sağlamış olup hem de müşterilerinin ekstra rol davranışlarını da arttırmaktadır. Hizmetten memnun kalan müşteriler işletmeyi tavsiye etme, geri bildirim sağlama, diğer müşterilere yardım etme ve hataları tolere etme gibi vatandaşlık davranışlarında bulunmaktadır. Müşterilerin gerçekleştireceği yardımseverlik davranışları işletmenin sorumluluklarını hafifletirken aynı zamanda müşteriler arasındaki sosyal bağı da güçlendirmektedir. Hizmetten yeteri düzeyde faydalanamayan müşteri, başka bir müşteri tarafından doğru yönlendirildiği takdirde hem memnuniyetsizliğin önüne geçilmiş hem de müşterilerin arasındaki ilişki gelişmiş olacaktır. Farklı bir alt boyut olan tolere etme davranışında ise işletmeden hizmet alan müşterilerin yapılan hataları hoş görmesi çalışanın öz güven düşüklüğü yaşamasının önüne geçebilmektedir. Tüm bu durumlara bakıldığında yiyecek içecek işletmelerinde vatandaşlık davranışı gösteren müşterilerin varlı̆̆ oldukça önemli olmakta ve yöneticilerin bu davranışları arttıracak çalışmalar içerisinde olmaları gerekmektedir.

Analizlerin devamında hizmet kalitesinin alt boyutlarının müşteri vatandaşlık davranışı üzerindeki etkisini belirlemeye yönelik çoklu doğrusal regresyon analizi yapılmıştır. Hizmet kalitesinin alt boyutlarının müşteri vatandaşlık davranışı üzerindeki etkisini belirlemeye yönelik regresyon analizinde güvenilirlik alt boyutunda gerçekleşen 1 birim artış müşteri vatandaşlık davranışı üzerinde 0,025'lik bir artış yaratmaktadır. Hizmet kalite ölçeğinde bulunan güvenilirlik alt boyutunun ifadeleri arasında problemlerin hızlıca çözülmesi, işletmenin vaatleri ile tutarlı hizmet sunumu, müşterinin istediği şekil ve sürede servis yapılması ve hesapların doğru tutulması yer almaktadır. Regresyon analizi sonuçlarına göre bu ifadelerin müşteri vatandaşlık davranışı üzerinde anlamlı bir etkisi olmadığı saptanmıştır. Bulgular sonucunda "Hizmet kalitesinin güvenilirlik alt boyutunun, müşteri vatandaşlı davranışı üzerinde anlamlı bir etkisi vardır $\left(\mathrm{H}_{\mathrm{a}}\right)^{\prime \prime}$ hipotezi desteklenmemiştir.

Regresyon analizinde heveslilik alt boyutunda gerçekleşecek olan 1 birimlik artışın müşteri vatandaşlık davranışına 0,175 düzeyinde etki etmektedir. Madani ve arkadaşları (2015) tarafından çalışanların vatandaşlık davranışı ve müşteri vatandaşlık davranışı arasındaki etkiye yönelik yaptıkları araştırmada, hizmet sunumu sırasında çalışanların gönüllü davranışları ne kadar fazla olursa müşterilerinde mevcut hizmetleri sağlamak için çalışanlar ile işbirliği yapma niyetlerinin o kadar fazla olduğunu saptanmıştır. Hizmet sektöründeki önemli faktörlerden birisi müşterilerle kurulan iletişimin niteliğidir. Bu konu üzerine işletmeler tarafından çalışanlara verilecek eğitimlerin işletme imajı ve karlılığı için önemli olduğu unutulmamalarıdır. İşletme yöneticilerinin çalışanları da motive edici stratejilerini geliştirmeleri önemli hale gelmektedir. Müşteri vatandaşlık davranışı motive edici yöntemlere yoğunlaşırken çalışanların motivasyon kaybı da durumu olumsuz etkileyecektir. Çünkü müşterilerin hizmet aldıkları esnada iletişim halinde bulundukları kişiler, işletmeyi temsil eden çalışanlar olmaktadır. Bulgular doğrultusunda "Hizmet kalitesinin heveslik alt boyutunun, müşteri vatandaşlık davranışı üzerinde anlamlı bir etkisi vardır $(\mathrm{Hb})$ " hipotezi desteklenmiştir.

Güven telkin etme alt boyutunda gerçekleşecek olan 1 birimlik artışın müşteri vatandaşlık davranışı üzerinde 0,061'lik bir etkisi olduğu belirtilmektedir. Hizmet kalite ölçeğinde güven telkin etme alt boyutlarının ifadeleri içerisinde, çalışanların müşterilere bilgi vermeye gönüllü olması, müşterilerin işletme içerisinde kendilerini güvende ve rahat hissetmeleri, çalışanların yetenekli ve deneyimli olması gibi ifadeler yer almaktadır. Ve müşteri vatandaşlık davranışı üzerinde bir etkisi olmadığı regresyon analizi ile saptanmıştır. İfadeler baktığımızda müşterilerin psikolojik ihtiyaçları da söz konusu olmaktadır ve çalışmada bu ihtiyaçların müşteri vatandaşlık davranışı üzerinde etkisi olmadığı saptanırken Chen vd. (2015) kişilerin psikolojik ihtiyaçlarının müşteri vatandaşlık davranışı üzerinde etkisi olduğunu savunmaktadır. Elde edilen bulgular sonucunda "Hizmet kalitesinin güven telkin etme alt boyutunun, müşteri vatandaşlık davranışı üzerinde anlamlı bir etkisi vardır $\left(\mathrm{H}_{\mathrm{c}}\right)$ " hipotezi desteklenmemiştir.

Empati alt boyutunda gerçekleşecek olan 1 birimlik artış müşteri vatandaşlık davranışı üzerinde 0,398 değerinde artışa sebep olacaktır. Empati boyutu müşteriler ile ilişkilerde oldukça önemli olmakta ve işletme 


\section{N. Yarmac1 - E. Kefeli 12/4 (2020) 3947-3964}

yöneticileri çalışanları bilgi ve beceri yönünden güçlendirerek müşteri ve çalışan arasındaki ilişkinin de kalitesini sağlamalıdır. İşletme çalışanları müşterilere karşı duyarlı ve yardımsever davranışlar sergilediklerinde ve belirtilen rollerinin ötesine geçtiklerinde aynı şekilde müşteriler de kendileri için belirlenmiş rollerin ötesine geçmektedir (Bove vd., 2009). Yu-hong, Da-hoi ve Shang-nan (2013) ve Balaji (2014), aynı zamanda ilişki kalitesinin müşteri vatandaşlık davranışı üzerinde olumlu etkisi olduğu da kanitlanmıştır. Macintosh (2007)' da kişiler arası ilişkilerin müşterileri işletmeye bağlayan ek bir bă̆ oluşturabileceğini saptamıştır. Müşteri davranışlarının aynı zamanda çalışanlar üzerinde de hayati önemi bulunmakta ve müşteri davranışlarına odaklanmak yönetimsel bir zorunluluk olmaktadır. Bu önem göz önüne alındığında yöneticiler müşterileri, çalışan performansını ve firma performansını iyileştirmek için katılım ve vatandaşlık davranışlarını motive etmelidir. Müşteriler ve çalışanlar arasındaki etkileşim, müşteri ihtiyaç ve beklentilerini daha iyi belirleyebileceğinde başarılı müşteri davranışı yönetimi sağlayabilir (Yi vd., 2011). Choi ve Letz (2016), çalışmasında müşteri vatandaşlık davranışından sadece işletmelerin değil aynı zamanda müşterilerinde faydalandığını (başarı duygusu) belirtmektedir. İşletmeler müşteriler ile ne kadar iyi ilişkiler kurarsa o kadar iyi müşteri vatandaşlık davranışını teşvik etmiş olur. Bulgular doğrultusunda "Hizmet kalitesinin empati alt boyutunun, müşteri vatandaşlık davranışı üzerinde anlamlı bir etkisi vardır $\left(\mathrm{H}_{\mathrm{d}}\right)$ " hipotezi de desteklenmiştir.

Fiziksel özellikler alt boyutunda gerçekleşecek olan 1 birimlik artışın da müşteri vatandaşlık davranışı üzerinde 0,174 'lük bir etki yaratacağ tespit edilmiştir. Hizmet kalite ölçeğinin ifadelerinde betimsel analiz yaparken belirtildiği gibi "fiziksel özellikler" alt boyutu burada da müşteri vatandaşlık davranışı üzerinde anlamlı bir etkiye sahip olduğu saptanmıştır. İşletmelerin fiziksel görünüşü, müşteriler ile iletişimde olan çalışanların dış görünüşü ya da işletmede kullanılan ekipmanlar müşteriler ile işletme arasında iletişim sağlayarak olumlu bir algı yaratmaktadır. Literatür kısmında müşterilerin hizmet alırken somut ipucu bulmakta zorlandığını ve genellikle işletmedeki fiziksel olanakları ipucu olarak algıladıklarını (Parasuraman vd., 1985), aynı zamanda bunların müşteri ile kurulan iletişimin birer parçası olduğu belirtilmektedir (Ladhari, Brun, ve Morales, 2008). Bulgular sonucunda "Hizmet kalitesinin fiziksel özellikler alt boyutunun, müşteri vatandaşlık davranışı üzerinde anlamlı bir etkisi vardır $\left(\mathrm{H}_{\mathrm{e}}\right)^{\prime \prime}$ hipotezi de desteklenmiştir.

Elde edilen bulgular müşterilerin almış olduğu kaliteli hizmetin müşteri vatandaşlık davranışını olumlu anlamda etkilediğini ortaya koymuştur. Bu doğrultuda, konu ile ilgili literatüre, araştırmacılara ve işletme yöneticilerine yönelik öneriler aşağıda sıralanmaktadır.

- Araştırma sürecinde müşteri vatandaşlık davranışının yeni bir kavram olmasından dolayı Türkçe kaynak sıkıntısı yaşanmış ve bu çalışmanın da literatürdeki boşluğa katkı sağlaması amaçlanmıştır. Araştırma evren ve örneklemi İstanbul ilindeki 1.Sınıf Restoranlar ile sınırlı kalmıştır. Gelecek çalışmalar farklı illerde de yapılarak literatür genişletilebilir. Aynı şeklide farklı yiyecek içecek işletmelerinde de müşteri vatandaşlık davranış düzeyleri ölçülerek işletme türleri arasında kıyaslamalar yapılabilir. Örneğin fastfood ve fine dining restoranlardan hizmet alan müşterilerin müşteri vatandaşlık davranışı düzeyleri arasında yapılacak karşılaştırmalar literatür için önemli kaynak olacaktır.

- Müşteri vatandaşlık davranışının, müşterilerin almış oldukları hizmet kalitesinden önemli ölçüde etkilendiği saptandığından işletme yöneticileri belirli aralıklar ile müşterilerin hizmetten memnun kalma düzeylerini ölçebilirler. Bu müşteri hesabını istediğinde kısa bir anket formu ile müşteriyi sıkmayacak şekilde hazırlanmış sorularla zorunlu tutmadan yapılabilir. Uzun ve anlaşılması güç sorular ya da müşteri anketi doldurmaya zorunlu tutulduğunda gerçekçi cevaplar alınmasının önüne geçilebilir. Salgın sürecinde işletmeler hastalık riskini azaltmak için dijital menüye geçmeye başlamış, bunu müşterilerin telefonlarında okuttukları barkod ile sağlamaktadırlar. İşletmeler yine müşterilerin bu barkot ile kolayca ulaşabilecekleri bir anket formunu da sunabilirler.

- İşletmeler için yeni pazarlara açılmak farklı kitlelere ulaşmak oldukça önemlidir ve bunun için bütçeler ayrılarak çalışmalar yapılmaktadır. Çalışmada hizmet kalitesinin müşteri vatandaşlık davranışı alt boyutlarından tavsiye etme ile kuvvetli ilişkiye sahip olduğu belirlenmiştir. Buradan anlaşılacağ gibi işletmeler tanıtım faaliyetlerini müşterilerine kaliteli hizmet sunarak daha ucuz yöntemler ile gerçekleştirebileceklerinden dolayı öncelikleri daima hizmet kalitesi olmalıdır.

- Araştırmada fiziksel özelliklerin müşteri üzerinde oldukça olumlu etki bıraktığı ve müşterilerin kalite değerlendirmesi yaparken fiziksel faktörlere önem verdikleri belirlenmiştir. Bu doğrultuda yiyecek içecek işletmelerinde müşterilerin hizmet alacakları ortamlar ferah, huzurlu ve konforlu hale getirilebilmek için 
tavan ve zemin renklerinde açık tonlar kullanılmalıdır. Ortam havalandırması iyi ayarlanmalı veya müşterilerin tercih ettikleri dış mekânlarda ağaçlandırma yapılarak hoş alanlar yaratılmalıdır. Aynı zamanda müşterinin kullandığı ekipmanların (çatal, bıçak, kaşık, sosluklar baharatlıklar vb.) sağlam temiz ve göze hitap edecek şekilde estetik anlamda tercih edilmesi müşterilerde olumlu izlenim yaratacaktır. Farklı bir açıdan da işletmeler marka değeri oluşturarak müşterilerinin zihinlerinde bir yer edinmeye çalışarak rakiplerinden öne geçmeyi amaçlamaktadırlar. Bunu yaparken en önem vermeleri gereken nokta çalışan güçlendirilmesi ve eğitimidir. Zira işletmeyi müşteriye karşı temsil eden çalışanlar ve onların performanslarıdır.

- Müşteri vatandaşlık davranışı gönüllü eylemleri içerdiği için işletmelerin müşterilerini herhangi bir ödül ile vatandaşlık davranışına teşvik etmesi doğru olmayacaktır. Bunun yerine işletme yöneticileri müşterilerini de dahil ettikleri sosyal etkinlikler düzenleyerek ve bu etkinliklerde müşterilerin fikirlerini alarak onları da organizasyonun bir parçası haline getirilebilir. Müşteriler kendilerini değerli hissettiklerinde normalde yaptıkları rol davranışlarının ötesine geçerek işletmeyle kendisi arasında bağ oluşturup vatandaşlık davranışı sergileyebilir.

Genel olarak çalışma değerlendirildiğinde oldukça yeni bir kavram olan müşteri vatandaşlık davranışının yiyecek içecek işletmelerinde incelenmesi literatürdeki çeşitliliğe katkı sağlarken yapılacak yeni çalışmalar için de fikir oluşturacaktır. Elde edilen bulgularda müşterilerin hizmet kalite algılarının müşteri vatandaşlık davranışı üzerindeki olumlu etkilerini ortaya koymaktadır. Pazardaki yerlerini korumak isteyen işletmelerinden hizmet alacak müşterilerin vatandaşlık davranışlarını da önemsenmelidir. Bu durum işletmelere stratejik anlamda da güç sağlayacaktır.

\section{Kaynakça}

Abolfathi, A., Tollabi, Z. and Pourashrf, Y. A. (2013). The Study Of The Relationship Between Perceived Quality of Electronic Services and Melli Bank Customers' Citizenship Behavior in Ilam Province, European Online Journal of Natural and Social Sciences, 3(2), 1159-1168.

Agrawal, A. K. and Rahman, Z. (2015). Roles and Resource Contributions of Customers in Value Co-creation, International Strategic Management Review, 3, 144-160.

Angelova, B. ve Zekiri, J. (2011). Measuring Customer Satisfaction with Service Quality Using American Customer Satisfaction Model (ACSI Model), International Journal of Academic Research in Business and Social Sciences, 3(1), 232-258.

Aracı, Ü. E. ve Sezgin, E. K. (2020). Müşteri Vatandaşlık Davranışı Ölçeğinin Geçerlilik ve Güvenilirlik Çalışması, Türk Turizm Araştırmaları Dergisi, 4(2) 1279-1293.

Balaji, M.S. (2014). Managing Customer Citizenship Behavior: A Relationship Perspective, Journal of Strategic Marketing, 22(3), 222-239.

Batson, C. D. and Shaw, L. L (1991). Evidence for Altruism: Toward a Pluralism of Prosocial Motives, Psychological Inquiry, 2(2), 107-122.

Bettencourt, L. A. (1997). Customer Voluntary Performance: Customers As Partners in Delivery, Journal of Retalling, 73(3), 383-406.

Bilgin, Y. ve Kethüda, Ö. (2017). Restoran İşletmelerinde Hizmet Kalitesinin Müşteri Memnuniyetine ve Sadakatine Etkisi: Oba Restoran Örneği, Çankırı Karatekin Üniversitesi İktisadi ve İdari Bilimler Fakültesi Dergisi, 2(7), 147-170.

Bougoure, U. and Neu, M. (2010). Service Quality in the Malaysian Fast Food Industry: An Examination Using DINESEVR, Services Marketing Quarterly, 31, 194-212.

Chai, J. C. Y., Malhotra, N. K. and Alpert, F. (2015). A Two-Dimensional Model of Trust-Value-Loyalty in Service Relationships, Journal of Retailing and Consumer Services, 26, 23-31.

Chen, K. H., Hsieh, K. J., Chang, F. H. and Chen, N. C. (2015). The Customer Citizenship Behaviors of Food Blog Users, Journal Sustainability, 7, 12502-12520 
N. Yarmac1 - E. Kefeli 12/4 (2020) 3947-3964

Choi, L. and Lotz, S. (2016). Motivations Leading to Customer Citisenship Behavior in Services: Scale Development and Validation, Journal of Consumer Marketing, 33(7), 539-551.

Cronin, J. J. and Taylor, S. A. (1992). Measuruing Services Quality: A Reexamination and Extension, Journal of Marketing, 56, 55-68.

Dewalska-Opitek, A. and Mitrega, M. (2019). Appreciate Me and I Will Be Your Good Soilder'. The Exploration of Antecedents to Consumer Citizenship, Engineering Management in Production And Services, 11(3), 4859.

Doğan, Ö. İ. ve Tütüncü, Ö. (2003). Hizmet İşletmelerinde Toplam Kalite Yönetimi Kapsamında ISO 9001: 2000 ve Bilgisayar Destekli Bir Uygulama, İzmir: Dokuz Eylül Üniversitesi Rektörlük Matbaası.

Edvardsson, B. (1998). Service Quality Improvement, Managing Service Quality, 8(2), 142-149.

Ferraz, S. B. (2018). Customer as Fellows: Analyzing Customer Citizenship Behavior in Services Marketing, Universidade de Sao Paulo Faculdade de Economia.

Fisher, J. D., Fisher, W. A, Amico, K. R. and Harman, J. J. (2006). An Information-Motivation-Beavioral Skills Model of Adherece to Antiretroviral Therapy, Health Psychology, 25(4), 462-473.

Fowler, J. G. (2013). Customer Citisenship Behavior: An Expanded Theoretical Understanding, International Journal of Business and Social Science, 4(5), 1-8.

Gelibolu, L. ve Kerse, Y. (2018). Yükseköğretimde Hizmet Kalitesinin Müşteri Vatandaşlık Davranışına Etkisi, Cumhuriyet Üniversitesi İktisadi ve İdari Bilimler Dergisi, 19(1), 361-380.

Groth, M. (2005). Customers as Good Soldiers: Examining Citizenship Behaviors in Internet Service Deliveries, Journal of Management, 1(3), 7-27.

Halis, M. (2010). Toplam Kalite Yönetiminin Temel Kavramları Demirkol \& Halis (Editör), Turizm İşletmelerinde Toplam Kalite Yönetimi, Değişim Yayıncılık, 1-34.

İstanbul İl Kültür ve Turizm Müdürlügüu, (2020), 2019 Yılı İstanbul'daki Turizm İşletmesi ve Turizm Yatırımı Belgeli Tesisler ve Deniz Turizmi Araçları ile İlgili İstatistikler, https://istanbul.ktb.gov.tr/TR268212/turizm-isletmesi-ve-turizm-yatirimi-belgeli-tesisler-ve-.html, (Erişim tarihi: 18\06\2020).

Jeong, H and Moon, J. (2009). Virtual Social Identify Development for Customer Electronic Word-of Mounth Participation, The 9th Intenational Conference on Electronic Business, 4, 243-249.

Jung, J. H. and Yoo, J. J. (2017). Customer-to-Customer Interactions on Customer Citizenship Behavior, Service Business, 11(1), 117- 139.

Kang, G. and James, J. (2014). Service Quality Dimensions: An Examination of Grönroos's Service Quality Model, Managing Service Quality, 14(4), 266-277.

Kılıç, B. ve Kurnaz, A. (2012). Yiyecek İçecek İşletmelerinde Hizmet Kalitesinin Dineserv Modeli ile Ölçümü, Finans Politik ve Ekonomik Yorumlar, 49(564), 87-104.

Kılıçhan, R. ve Ülker, M. (2015). Fast Food Restoranlarının Hizmet Kalitesinin DINESERV Modeli ile Ölçülmesi: Kayseri İli Örneği, 16. Ulusal Turizm Kongresi Bildiriler El Kitabı, Ankara: Detay Yayıncllık, 885-904.

Kozak, M. (2018). Bilimsel Araştırma: Tasarım, Yazım ve Yayım Teknikleri, Detay Yayıncılık: Ankara.

Ladhari, R., Brun, I. and Morales, M. (2008). Determinants od Dining Satisfaction and Post-Dining Behavioral Intentions, International Journal of Hopitality Management, 27, 563-573.

Lee, Y. Choi, B. Kim, D. J. and Hyun, S. S. (2014). Relational Benefits, Their Consequences, and Customer Membership Types, The Service Industries Journal, 34(3), 230-250.

Lengnick-Hall, C. A. (1996). Customer Contributions to Quality: A Different View of The Customer-Oriented Firm, Academy of Management Review, 21(3), 791-824.

Lewis, B.R. and Mitchell, V. W. (1990). Defining and Measuring the Quality of Customer Service, Marketing Intelligence \& Planning, 8, 11-17. 
N. Yarmac1 - E. Kefeli 12/4 (2020) 3947-3964

Macintosh, G. (2007). Customer Orientation, Relationship Quality, and Relational Benefits to The Firm, Journal of Services Marketing, 3(21), 150-159.

Madani, F. A., Hosseini, S. H., Kordnaeji, A. and Isfahani, A.M. (2015). Intellectual Capital: Investigating The Role of Customer Citizenship Behavior and Employee Citizenship Behavior in Banking Industry in Iran, Management and Adminisrative Sciences Review, 4(4), 736-747.

Meidute-Kavaliauskiene, I., Aranskis, A. and Litvinenko, M. (2014). Consumer Satisfaction with The Quality of Locistics Services, Social and Behavioral Sciences, 110, 330-340.

Mosavi, S. A. and Ghaedi, M. (2012). A Survey on The Relationships Between Customer Satisfaction, Image, Trust and Customer Advocacy Behavior, African Journal of Business Management, 6(8), 2897-2910.

Nagy, E. S. A. and Marzouk, W. G. (2018). Factors Affecting Customer Citizenship Behavior: A Model of University Students, International Journal of Marketing Studies, 10(1), 54-70.

Parasuraman, A., Zeithaml, V. A. and Berry, L. L. (1985). A Conceptual Model of Service Quality and Its Implications for Future Research, Journal of Marketing, 49, 41-50.

Raajpoot, N. A. (2002). TANGSERV: A Multiple Item Scale for Measuring Tangible Quality in Foodservice Industry, Journal of Foodservice Business Research, 5(2), 109-127.

Şimşek, H. (2013). Toplam Kalite Yöntemi Kuramlar, İlkeler, Uygulamalar. Ankara: Seçkin Yayıncılık, 2. Basım.

Şirin, M. E. \& Aksu M. (2016). Otel İşletmelerinde Hizmet Kalitesinin Müşteri Memnuniyeti, Tekrar Satın Alma ve Tavsiye İsteği Üzerine Etkisi: Trabzon Ortahisar Örneği, Sosyal Bilimler Enstitüsü Dergisi, 6(2), 530544.

Türkmen, G. (2019). Müşteri Vatandaşlık Davranışı, Detay Yayıncılık: Ankara.

Türkmen, H. G. and Nardalı S. (2017). Müşteri Vatandaşlık Davranışı Literatür Taraması, Uluslararası İktisadi ve İdari incelemeler Dergisi, 16.UİK Özel Sayısı, 865-878.

Yi, Y., Gong, T. and Lee, H. (2013). The Impact of Other Customers on Customer Citizenship Behavior, Psychology and Marketing, 30(4), 341-356.

Yu-hong, Z., Da-hai, D. and Sheng-nan, L. (2013). Antecedents and the Outcome of Customer Citizenship Behavior in Consumption Virtual Communities: A Theoretical Model, International Conference on Education Technology and Management Science, June:2013, 614-617.

Zengin, E. ve Erdal, A. (2000). Hizmet Sektöründe Toplam Kalite Yönetimi, Journal of Qafqaz Universiy, 1(3), 43-56. 